4 Jennifer Röder ${ }^{1}$ and Michael Hensel ${ }^{1,2}$

9

Address for correspondence:

Michael Hensel

Abteilung Mikrobiologie

Barbarastr. 11

49076 Osnabrück, Germany

Tel: ++ 49 (0)541969 3940

Fax: ++ 49 (0)541 9693942

E-mail: Michael.Hensel@uni-osnabrueck.de

\title{
Single cell analyses reveal phosphate availability as critical factor for nutrition of Salmonella enterica within mammalian host cells
}

${ }^{1}$ Abteilung Mikrobiologie, ${ }^{2}$ CellNanOs - Center of Cellular Nanoanalytics, Fachbereich Biologie/Chemie, Universität Osnabrück, Osnabrück, Germany

ORCID 0000-0002-1682-6873 JR, 0000-0001-6604-6253 MH

Running title: Intracellular Salmonella phosphate availability

Keywords: intracellular pathogen, pathogen-containing vacuole, type III secretion system, single cell analyses, reporter techniques, invasion

CellNanOs - Center of Cellular Nanoanalytics Osnabrück

Fachbereich Biologie/Chemie, Universität Osnabrück 
Intracellular Salmonella phosphate availability

\section{Abstract}

Salmonella enterica serovar Typhimurium (STM) is an invasive, facultative intracellular pathogen that resides in a specialized membrane-bound compartment termed Salmonellacontaining vacuole (SCV). Essential for survival and proliferation in the SCV is Salmonella pathogenicity island II (SPI2) that encodes a type III secretion system (T3SS). The SPI2-T3SS and the effector translocation maintain SCV integrity and formation of specific tubular membrane compartments, called Salmonella-induced filaments (SIFs). The SCV/SIF continuum allows STM to bypass nutritional restriction in the intracellular environment by acquiring nutrients from the host cell. Phosphate is one of the most abundant elements in living organisms and in STM, inorganic phosphate $\left(\mathrm{P}_{\mathrm{i}}\right)$ homeostasis is mediated by the twocomponent regulatory system PhoBR, resulting in expression of the high affinity phosphate transporter pstSCAB-phoU. Using fluorescent protein reporters, we investigate $\mathrm{P}_{\mathrm{i}}$ availability for STM at single cell level over time within the intracellular habitats of different host cells. We observed that the pstSCAB-phoU encoded phosphate uptake system is essential for intracellular replication of STM because there is a $P_{i}$ ion concentration less $10 \mu \mathrm{M}$ within the SCV. Additionally, the demand and consumption of $\mathrm{P}_{\mathrm{i}}$ correlates with intracellular proliferation of STM and we identify a dependency of SPI2 activity and $\mathrm{P}_{\mathrm{i}}$ starvation. 
bioRxiv preprint doi: https://doi.org/10.1101/2020.10.23.351551; this version posted October 23, 2020. The copyright holder for this preprint (which was not certified by peer review) is the author/funder, who has granted bioRxiv a license to display the preprint in perpetuity. It is made available under aCC-BY-NC-ND 4.0 International license.

Intracellular Salmonella phosphate availability

44

45

46

47

48

49

50

51

52

53

54

55

56

57

58

59

60

61

62

63

64

65

66

67

68

69

\section{Introduction}

Microbial pathogens have to adapt to the specific nutritional landscape provided by the host in order to survive and to proliferate. For intracellular bacteria, nutritional conditions within host cells may vary depending on the specific subcellular niche inhabited by the pathogen, the antimicrobial activity of the host cell, and the pathogen burden. Given the current antibiotics crisis due to increasing resistance and lack of novel antimicrobial compounds, bacterial nutrition within the host may provide new targets for non-antibiotic strategies to combat infectious diseases. Understanding bacteria nutrition within the host and/or host cells is prerequisite for such approaches, and we set out to investigate the nutritional requirements of Salmonella enterica, a food-borne pathogen causing diseases ranging from gastroenteritis to systemic typhoid fever.

S. enterica serovar Typhimurium (STM) is an invasive, facultative intracellular pathogen that resides in a specialized membrane-bound compartment termed Salmonella-containing vacuole (SCV) (Haraga, Ohlson, \& Miller, 2008). Essential for survival and proliferation in the SCV is a type III secretion system (T3SS) encoded by Salmonella pathogenicity island 2 (SPI2) (Hensel et al., 1998). The SPI2-T3SS and the translocated effector proteins maintain the SCV integrity and mediate formation of specific tubular membrane compartments, called Salmonella-induced filaments (SIFs) (Brumell, Tang, Mills, \& Finlay, 2001; Drecktrah, Knodler, Howe, \& SteeleMortimer, 2007; Figueira \& Holden, 2012; Rajashekar, Liebl, Seitz, \& Hensel, 2008). Formation of an extensive SIF network by STM was suggested to provide bacterial nutrition and enabling proliferation (Liss et al., 2017). Mutant strains defective in SPI2-T3SS are attenuated in systemic virulence and show reduced intracellular replication (Hensel et al., 1995; Hensel et al., 1998). An important SPI2-T3SS effector protein is SifA, as lack of this effector leads to defects in remodeling of the host cell endosomal system and maintenance of intact SCV (Beuzon et al., 2000; Stein, Leung, Zwick, Garcia-del Portillo, \& Finlay, 1996). Deletion of sifA attenuates virulence, replication in macrophages (Beuzon et al., 2000; Brumell, 
bioRxiv preprint doi: https://doi.org/10.1101/2020.10.23.351551; this version posted October 23,2020 . The copyright holder for this preprint (which was not certified by peer review) is the author/funder, who has granted bioRxiv a license to display the preprint in perpetuity. It is made available under aCC-BY-NC-ND 4.0 International license.

Intracellular Salmonella phosphate availability

Rosenberger, Gotto, Marcus, \& Finlay, 2001), and results in hyper-replication of STM in the nutrient-rich cytosol of epithelial cells (Knodler, 2015).

Intracellular STM show a remarkable heterogeneity regarding proliferation and response to environmental cues (Bumann \& Cunrath, 2017; Helaine et al., 2014). Subpopulations are present in SCV or cytosol, are actively proliferating or dormant (Helaine et al., 2014; Knodler, 2015). For analyses of the intracellular environment of STM and responses to intracellular cues, this heterogeneity restricts the application of population-wide approaches such as transcriptomics or proteomics. Such analyses on the level of single intracellular bacteria are still pending. However, bacteria can be used as sensitive tools to interrogate the response to specific environmental cues, and fluorescent protein reporters in combination with flow cytometry (FC) allows efficient single cell analyses of large and heterogenous populations.

We set out to systematically analyze the availability of nutrients for intracellular STM in mammalian host cells on the single cell level. Here, we focus on the role of phosphate for intracellular STM. Phosphorus is one of the most abundant elements in living organisms, found in membrane lipids, nucleic acids, proteins or carbohydrates, and involved in many enzymatic reactions. In bacteria, inorganic phosphate $\left(\mathrm{P}_{\mathrm{i}}\right)$ homeostasis is mediated by the two-component regulatory system PhoBR. The membrane-bound sensor PhoR reacts to low $\mathrm{P}_{\mathrm{i}}$ and activates PhoB, a transcriptional regulator that promotes the expression of many genes involved in $\mathrm{P}_{\mathrm{i}}$ transport (Hsieh \& Wanner, 2010). This includes transcription of the pstSCAB-phoU operon encoding a high affinity phosphate transporter. PstS is a periplasmic protein that binds $\mathrm{P}_{\mathrm{i}}$ with high affinity. PstC, PstA and PstB form an ABC transporter with PstC and PstA being inner membrane channel proteins and PstB an ATP-dependent permease component. PhoU is essential for the suppression of the Pho regulon under a high phosphate condition (Wanner, 1996). The exact mechanism of action of PhoU is not yet understood (Gardner, Johns, Tanner, \& McCleary, 2014). Several studies link the $\mathrm{P}_{\mathrm{i}}$ homeostasis with virulence of bacteria as well as for STM (Lamarche, Wanner, Crepin, \& Harel, 2008). 
bioRxiv preprint doi: https://doi.org/10.1101/2020.10.23.351551; this version posted October 23, 2020. The copyright holder for this preprint (which was not certified by peer review) is the author/funder, who has granted bioRxiv a license to display the preprint in perpetuity. It is made available under aCC-BY-NC-ND 4.0 International license.

Intracellular Salmonella phosphate availability and concentration of $\mathrm{P}_{\mathrm{i}}$ during infection of host cells by STM. host cell.

Expression of SPI2-T3SS genes is activated within the SCV of host cells, and the proper spatiotemporal control ensures activity of virulence factors in the required phase of hostpathogen interaction. The intracellular habitat of STM is a complex environment with a multiplicity of stressors and nutritional limitations, thus specific stimuli are difficult to dissect. In contrast, systematic analyses of expression under defined in vitro conditions identified a slightly acidic $\mathrm{pH}, \mathrm{Mg}^{2+}$ limitation, and $\mathrm{P}_{\mathrm{i}}$ starvation as stimuli inducing SPI2 gene expression (Deiwick \& Hensel, 1999). The SPI2-T3SS-dependent endosomal remodeling and induction of a complex SCV/SIF continuum allows intracellular STM to relieve nutritional limitations (Liss et al., 2017). Accordingly, we anticipate a link between nutritional limitation in the intracellular environment, control of SPI2 gene expression, and SPI2-T3SS-mediated manipulation of the

Phosphate uptake and the regulation of $\mathrm{P}_{\mathrm{i}}$ homeostasis by pstSCAB-phoU were suggested to be essential for the pathogenicity of STM. Various studies indicated upregulation during infection (Garcia-del Portillo, Foster, Maguire, \& Finlay, 1992; Hautefort et al., 2008). Thus, we investigated $\mathrm{P}_{\mathrm{i}}$ availability for STM at a single cell level over time within distinct intracellular habitats of different host cells. Therefore, we generated reporters and measured the presence 
bioRxiv preprint doi: https://doi.org/10.1101/2020.10.23.351551; this version posted October 23, 2020. The copyright holder for this preprint (which was not certified by peer review) is the author/funder, who has granted bioRxiv a license to display the preprint in perpetuity. It is made available under aCC-BY-NC-ND 4.0 International license.

Intracellular Salmonella phosphate availability

114

\section{Results}

The pstSCAB phoU-encoded phosphate uptake system is required for intracellular proliferation of STM

We investigated the relevance of $\mathrm{P}_{\mathrm{i}}$ uptake for the intracellular lifestyle of STM. Various genes involved in regulation of $\mathrm{P}_{\mathrm{i}}$ homeostasis were deleted and intracellular proliferation of the resulting mutant strains in comparison to STM WT were determined using competitive index (CI) assays (Figure 1). The SPI2-T3SS-deficient strain $\Delta s s a V$ served as negative control for intracellular replication (Hensel et al., 1998) and showed a low CI of 0.1, both in HeLa cells and RAW264.7 macrophages. The pstSCAB operon encodes for an ABC transporter, mediating the phosphate uptake (Lamarche et al., 2008). Deletion of this transporter resulted in a CI of 0.4 in both host cell types. This high-affinity phosphate transporter is regulated by the phoBR two-component system (Lamarche et al., 2008). Deletion of phoB or phoR attenuated intracellular replication. In HeLa cells, CI of 0.2 or 0.3 were determined for $\Delta p h o B$ or $\Delta p h o R$ strains, respectively, and within RAW264.7 macrophages as host cells, CI of 0.5 or 0.6 for $\Delta p h o B$ or $\Delta p h o R$ strains, respectively, were determined.

A particularly interesting phenotype was observed by deletion of phoU. While in RAW264.7 macrophages phagocytosis was not affected, replication was impaired with a CI of 0.1. A $\Delta$ phoU strain showed reduced growth in LB medium and formed smaller colonies compared to STM WT. PhoU plays a key role in phosphate homeostasis by repressing the pho regulon at high phosphate levels (Gardner et al., 2014). SPI1-T3SS-mediated invasion of HeLa cells was below the detection limit, probably due to the reduced growth rate. This resulted in a highly reduced CI for $\Delta p h o U$ vs. WT in HeLa cells. In contrast, lack of PhoE, an outer membrane protein for uptake of inorganic phosphates (Spierings, Elders, van Lith, Hofstra, \& Tommassen, 1992), did not affect intracellular replication as CI of 0.7 and 1 in HeLa and RAW264.7, 
bioRxiv preprint doi: https://doi.org/10.1101/2020.10.23.351551; this version posted October 23,2020 . The copyright holder for this preprint (which was not certified by peer review) is the author/funder, who has granted bioRxiv a license to display the preprint in perpetuity. It is made available under aCC-BY-NC-ND 4.0 International license.

Intracellular Salmonella phosphate availability

138 respectively, were determined. Therefore, we conclude that proper $\mathrm{P}_{\mathrm{i}}$ homeostasis plays a 139 central role for intracellular replication and virulence of STM.

140 Generation and validation of reporter strains for measuring inorganic phosphate levels

141 Phosphate uptake by the transporter PstSCAB, as well as regulation of this system by PhoBR,

142 proved to be of critical importance for intracellular proliferation. This prompted us to

143 investigate availability of $\mathrm{P}_{\mathrm{i}}$ for intracellular STM in more detail. Intracellular STM diversify

144 into various subpopulations, i.e. bacteria being located vacuolar or cytosolic, proliferating

145 slowly or rapidly, or forming non-replicating persisters. This heterogeneity demands analyses

146 on level of single cell of intracellular STM. In order to determine the intracellular $\mathrm{P}_{\mathrm{i}}$

147 concentration more precisely, we generated a dual fluorescence reporter with constitutive

148 expression of DsRed, and sfGFP under control of the promoter of pstS. PstS is a periplasmic

149 protein that binds $\mathrm{P}_{\mathrm{i}}$ with high affinity and is known to be upregulated intracellularly in $\mathrm{P}_{\mathrm{i}}$-poor

150 environments (Hautefort et al., 2008).

151 STM was subcultured for $3.5 \mathrm{~h}$ or $24 \mathrm{~h}$ in media with various concentrations of $\mathrm{P}_{\mathrm{i}}$, and

152 expression of $\mathrm{P}_{p s t s:: s f G F P}$ was determined by FC. Induction of $\mathrm{P}_{p s t s:: s f G F P}$ was detected after

153 growth in media containing $\mathrm{P}_{\mathrm{i}}$ concentrations of $1 \mathrm{mM}$ or lower, and sfGFP intensity increased

154 as $\mathrm{P}_{\mathrm{i}}$ concentration decreased (Figure 2AB). Comparison of $\mathrm{P}_{p s t s}$ ::sfGFP intensities between cells of $3.5 \mathrm{~h}$ and $24 \mathrm{~h}$ subcultures revealed higher intensity in late cultures (Figure 2C). This would be in line with the consumption of the $\mathrm{P}_{\mathrm{i}}$ pool during STM growth resulting in $\mathrm{P}_{\mathrm{i}}$ limitation, and/or accumulation of the reporter. To precisely determine the $\mathrm{P}_{\mathrm{i}}$ concentration

158 critical for induction of phosphate reporter $\mathrm{P}_{p s t}:$ :sfGFP, we performed a phosphate shock

159 experiment (Figure 2DE). A logarithmic culture was used to inoculate media with various $\mathrm{P}_{\mathrm{i}}$ concentrations and incubation was continued for $1 \mathrm{~h}$. This regime minimized the change in $\mathrm{P}_{\mathrm{i}}$

161 levels due to consumption by bacterial growth, and we detected induction of the phosphate reporter at concentrations below $100 \mu \mathrm{M}$. Decreasing $\mathrm{P}_{\mathrm{i}}$ concentrations correlated with increasing sfGFP intensities, and sfGFP intensity of $10^{4}$ relative fluorescence intensity (RFI) 
bioRxiv preprint doi: https://doi.org/10.1101/2020.10.23.351551; this version posted October 23, 2020. The copyright holder for this preprint (which was not certified by peer review) is the author/funder, who has granted bioRxiv a license to display the preprint in perpetuity. It is made available under aCC-BY-NC-ND 4.0 International license.

Intracellular Salmonella phosphate availability

164 indicated a concentration of less than $10 \mu \mathrm{M} \mathrm{P}_{\mathrm{i}}$ (Figure 2F). The effect of mutations in

165 phosphate transporters or regulatory systems on the expression of the phosphate reporter was

induction of $\mathrm{P}_{p s t s}:$ :sfGFP was detected. However, a $\Delta p h o U$ strain demonstrated strong induction of $\mathrm{P}_{p s t s:: s f G F P}$ in PCN (0.4), as well as in PCN (25) despite sufficient phosphate availability.

Only moderate growth was observed for this mutant strain, indicating missing repression of

171 from PCN (25) to PCN (0.4), $\triangle p s t S A C B, \triangle p h o B$ and $\triangle p h o R$ strains did not respond to low

172 phosphate concentrations. Therefore, no regulation of the high-affinity $\mathrm{P}_{\mathrm{i}}$ uptake system was

173 possible in these mutant strains.

174 Heterogeneity of the intracellular bacterial populations

175 After validation of the phosphate reporter, we deployed the system in infection assays of HeLa

176 cells and RAW264.7 macrophages. Due to the different sfGFP intensities, we detected 177 heterogeneous STM populations in HeLa cells and RAW264.7 macrophages. After infection of

178 HeLa cells, three subpopulations were detected at $8 \mathrm{~h}$ post-infection (p.i.) (Figure 3ABC). The

179 classification of $\mathrm{P}_{\mathrm{i}}$ availability was based on the intensities determined by in vitro experiments.

180 A very small population P1 was non-induced, a large population P2 (ca. 90\%) indicated $\mathrm{P}_{\mathrm{i}}$

181 concentrations above $10 \mu \mathrm{M}$, and a small population P3 (4\%) corresponded to concentrations

182 below $10 \mu \mathrm{M} \mathrm{P}_{\mathrm{i}}$. At 16 h p.i., P3 of STM WT (34\%) and $\Delta$ ssaV strains (18.5\%) increased, while

183 the $\Delta$ sifA strain remained predominantly in P2 (88\%). Since a sifA mutant strain has access to

184 cytosolic components due to compromised SCV integrity (Beuzon et al., 2000), we assumed a

185 higher $\mathrm{P}_{\mathrm{i}}$ concentration in the host cell cytosol. Therefore, we deduced for HeLa cells $\mathrm{P}_{\mathrm{i}}$

186 concentrations lower than $10 \mu \mathrm{M}$ in the SCV, and higher than $10 \mu \mathrm{M}$ in the cytosol. In

187 RAW264.7 macrophages, conditions were slightly different (Figure 3DEF). At 8 h p.i. we

188 distinguished between induced (55\% of STM WT and 52\% of $\Delta s s a V$ ) and non-induced 
bioRxiv preprint doi: https://doi org/10.1101/2020.10.23.351551; this version posted October 23, 2020. The copyright holder for this preprint (which was not certified by peer review) is the author/funder, who has granted bioRxiv a license to display the preprint in perpetuity. It is made available under aCC-BY-NC-ND 4.0 International license.

Intracellular Salmonella phosphate availability

189

190

191

192

193

194

195

196

197

198

199

200

201

202

203

204

205

206

207

208

209

210

211

212

213

populations, but all induced STM reported presence of less than $10 \mu \mathrm{M} \mathrm{P}_{\mathrm{i}}$. While the $\Delta s s a V$ strain showed $70 \% \mathrm{P}_{p s t s}$-positive bacteria at $16 \mathrm{~h}$ p.i., the STM WT showed $92 \%$ of $\mathrm{P}_{\text {psts-positive }}$ bacteria at 16 h p.i., including $25 \%$ of cells with lower DsRed and sfGFP intensity, indicative for concentrations of more than $10 \mu \mathrm{M} \mathrm{P}_{\mathrm{i}}$.

In overview images, STM WT indicated quite evenly distributed sfGFP intensities in HeLa cells (Figure 3G). However, in RAW264.7 macrophages the heterogeneity of DsRed and sfGFP intensities was more visible (Figure $3 \mathrm{H}$ ). The $\Delta s s a V$ strain (Figure S 3 ) also showed a relatively uniform distribution of sfGFP intensity in HeLa cells. In RAW264.7 macrophages, we distinguished between non-induced and induced bacteria, whereas the sfGFP intensity did not exhibit major differences.

We tested another phosphate reporter using the promoter of apeE, which codes for an outer membrane esterase. Expression of apeE was induced by phosphate limitation, and required the phoBR phosphate regulatory system (Conlin, Tan, Hu, \& Segar, 2001). This reporter led to comparable results. An in vitro induction was measured at concentrations below $1 \mathrm{mM}$ in a 3.5 h subculture and the sfGFP intensity increased with decreasing $\mathrm{P}_{i}$ values (Figure S 2A). The same subpopulations within HeLa cells (Figure S 2BCD) and RAW264.7 macrophages (Figure S 2EF) were observed, but generally the sfGFP intensity was lower.

Next, we analyzed induction of the phosphate reporter over the time course of infection. By comparing the reporter induction of STM WT and $\Delta s s a V$ strains in HeLa cells, we determined similar induction up to $10 \mathrm{~h}$ p.i., as percentage of sfGFP-positive STM and intensity of single

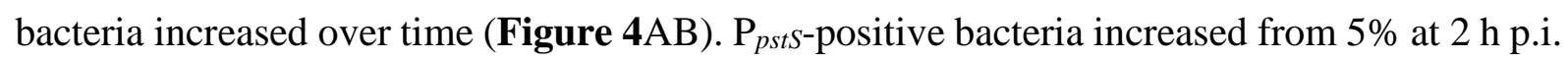
to $85 \%$ for STM WT, and to $62 \%$ for the $\Delta s s a V$ strain at $10 \mathrm{~h}$ p.i. At later time points, the $\Delta s s a V$ strain decreased to $34 \% \mathrm{P}_{p s t}$-induced cells, while STM WT continued to increase to $89 \%$ (Figure 4CD). This likely reflects the higher replication and metabolic activity of STM WT compared to STM $\Delta s s a V$ (Liss et al., 2017). 
bioRxiv preprint doi: https://doi.org/10.1101/2020.10.23.351551; this version posted October 23,2020 . The copyright holder for this preprint (which was not certified by peer review) is the author/funder, who has granted bioRxiv a license to display the preprint in perpetuity. It is made available under aCC-BY-NC-ND 4.0 International license.

Intracellular Salmonella phosphate availability

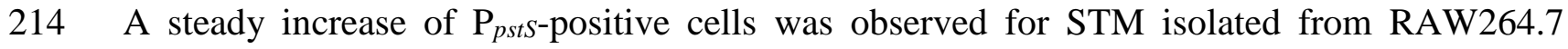

215 macrophages over time (Figure 4EF). With an increase from $60 \%$ at 2 h p.i. to $93 \%$ and $85 \%$

216 for STM WT and $\Delta s s a V$ strains, respectively, at $24 \mathrm{~h}$ p.i. The $\Delta s s a V$ strain exhibited slight

217 fluctuations, but over time between $60-85 \%$ of the bacteria were induced. In contrast, STM WT

218 showed a decline in sfGFP intensity at $10 \mathrm{~h}$ and later p.i. (Figure 4GH). Therefore, in HeLa

219 cells P3 $\left(<10 \mu \mathrm{M} \mathrm{P} \mathrm{P}_{\mathrm{i}}\right)$ became larger, and P2 $\left(>10 \mu \mathrm{M} \mathrm{P} \mathrm{P}_{\mathrm{i}}\right)$ smaller over time, because of

220 increasing sfGFP intensities. In RAW264.7 macrophages, a severe $P_{i}$ deficiency was already

221 detected in the early stages, and again replicating STM WT differ from non-replicating $\Delta s s a V$

222 strain after $10 \mathrm{~h}$ p.i.

223 Due to the different populations observed for STM WT and $\Delta$ sifA strains in HeLa cells, we

224 already assumed that access to cytosolic components led to increased phosphate availability.

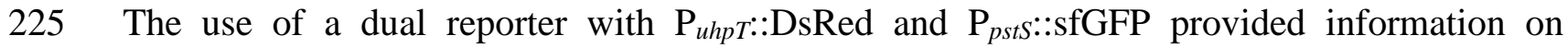

226 phosphate concentration over time in distinct habitats in HeLa cells (Figure 5A, Figure S 5A).

227 Puhpт induction indicates cytosolic presence of the bacteria (Röder \& Hensel, 2020). After

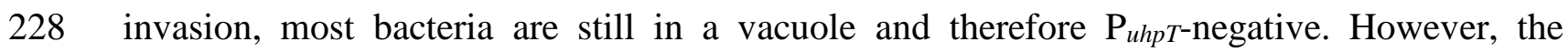

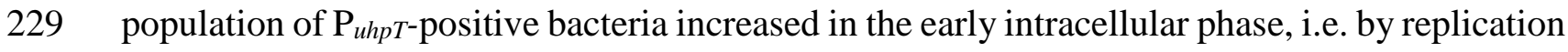

230 in the cytosol. At late time points ( $\geq 10$ h p.i.) change in intracellular population occurred, with

231 an increased vacuolar population, and declined of the cytosolic population. For STM WT, the

$232 \mathrm{P}_{\text {uhpt }}$-negative population increased from $54 \%$ at $10 \mathrm{~h}$ p.i. to $81 \%$ at $24 \mathrm{~h}$ p.i. The sfGFP

233 intensity increased, indicating decreased availability of $\mathrm{P}_{\mathrm{i}}$ in both habitats (Figure 5BC).

234 Similar results were obtained with a reporter using the correlation between $\mathrm{P}_{s s a G}:$ :DsRed and

$235 \mathrm{P}_{p s t}:$ :sfGFP (Figure 5D, Figure S 5B). The $s s a G$ gene is located in SPI2, encodes the needle

236 subunit of the T3SS, and was used to analyze expression of genes for the SPI2-T3SS (Lim,

237 Kim, Choi, Lee, \& Ryu, 2006). SPI2 induction is known for SCV-bound bacteria, but not for

238 cytosolic bacteria (Knodler et al., 2010). Accordingly, vacuolar replication also started $10 \mathrm{~h}$

239 p.i., as the $\mathrm{P}_{\text {ssaG }}$-positive population increased from $39 \%$ to $75 \%$ at 24 h p.i., but unlike the 
bioRxiv preprint doi: https://doi.org/10.1101/2020.10.23.351551; this version posted October 23, 2020. The copyright holder for this preprint (which was not certified by peer review) is the author/funder, who has granted bioRxiv a license to display the preprint in perpetuity. It is made available under aCC-BY-NC-ND 4.0 International license.

Intracellular Salmonella phosphate availability

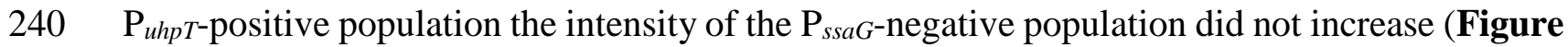
241 5EF). This may be attributed to the continuously rupture of the SCV by STM (Röder \& Hensel, 242 2020), i.e. STM escaped from a $\mathrm{P}_{\mathrm{i}}$-restricted SCV into the cytosol of host cells, and thus 243 erroneously enhanced the overall sfGFP intensity. Equally, cytosolic bacteria ( $\mathrm{P}_{\text {ssaG }}$-negative) 244 are unlikely to become vacuolar and exhibited continuously high sfGFP intensity. In 245 RAW264.7 macrophages, however, all bacteria were $\mathrm{P}_{\text {ssaG-positive (vacuolar), and only few }}$ 246 Puhpт-positive bacteria (cytosolic) were detected (Figure S 4). Therefore, STM mainly resides 247 inside the SCV of RAW264.7 macrophages.

248 We also analyzed the phosphate reporter in activated RAW264.7 macrophages and primary 249 human macrophages, which provided a more restrictive environment for bacteria resulting in 250 an attenuated replication (Lathrop et al., 2018; Rosenberger \& Finlay, 2002). If RAW264.7 251 macrophages activated with interferon- $\gamma$ (IFN- $\gamma$ ), were infected, we obtained mixed 252 populations for STM WT or $\Delta s s a V$ strains (Figure 6A). The induced bacterial population was 253 smaller (70\% and 95\% in activated and non-activated RAW264.7, respectively). However, the 254 intensity was higher, suggesting a lower $\mathrm{P}_{\mathrm{i}}$ concentration (Figure 6B).

255 In primary macrophages isolated from human peripheral blood we determined an even smaller 256 induced population (32\% and $26 \%$ at $8 \mathrm{~h}$ and $16 \mathrm{~h}$ p.i., respectively), but it is known that 257 proliferation for STM in these cells is highly restricted. Since only about $30 \%$ of the bacteria 258 were induced, the rest of the population may be dead, or have entered persister state (Figure 259 6CD). Although the population was much more widely distributed in RAW264.7 macrophages, 260 a similar average sfGFP intensity was measured at $16 \mathrm{~h}$ p.i., whereas at $8 \mathrm{~h}$ p.i. the sfGFP 261 intensity was much lower in human macrophages. However, in activated RAW264.7 262 macrophages, as well as in primary human macrophages, induction and thus phosphate 263 limitation was detected.

264 Reporters with destabilized sfGFP allow to measure rapid changes in phosphate availability 
bioRxiv preprint doi: https://doi.org/10.1101/2020.10.23.351551; this version posted October 23,2020 . The copyright holder for this preprint (which was not certified by peer review) is the author/funder, who has granted bioRxiv a license to display the preprint in perpetuity. It is made available under aCC-BY-NC-ND 4.0 International license.

Intracellular Salmonella phosphate availability

265

The sfGFP has a rather long half-life (Pedelacq, Cabantous, Tran, Terwilliger, \& Waldo, 2006) that limits analyses of STM responses to changing environments. To modify the reporter system for analyses of rapid changes in phosphate concentration, the LVA tag was fused to sfGFP resulting in increased degradation (Andersen et al., 1998). Analysis of induction in vitro in a phosphate shock experiment showed that slightly delayed induction occurred and signals were measured at a concentration of $10 \mu \mathrm{M} \mathrm{P}$, but not at $100 \mu \mathrm{M}$ (Figure 7A). At a concentration of $10 \mu \mathrm{M} \mathrm{P}_{\mathrm{i}}$ an intensity of $10^{3} \mathrm{RFI}$ was determined for sfGFP-LVA, compared to $10^{4} \mathrm{RFI}$ for the parental reporter, probably as consequence of the continuous degradation of sfGFP (Figure 7B). Therefore, we compared the stability of sfGFP and sfGFP-LVA by growing subcultures in PCN (0.01) media for $2 \mathrm{~h}$. Then, protein synthesis was stopped by chloramphenicol, and incubation continued. The sfGFP intensities of the cultures were determined at various time points after block of synthesis (Figure 7CD), and we observed that the LVA tag caused a continuous decline of sfGFP intensity and no sfGFP signals were detectable after $60 \mathrm{~min}$. For normal sfGFP, a constant signal was still detectable after $210 \mathrm{~min}$.

We used this reporter in STM infection of HeLa cells and observed hardly any difference between $\mathrm{P}_{p s t s:: s f G F P}$ and $\mathrm{P}_{p s t}:$ ::sfGFP-LVA (Figure 7EF). The percentages of induced bacteria were almost identical, while sfGFP intensity was lower if LVA was present. Nevertheless, the intensity of the destabilized sfGFP constantly increased, thus confirming a decrease in $\mathrm{P}_{\mathrm{i}}$ concentration over time of intracellular proliferation. In RAW264.7 macrophages, sfGFP intensity dropped after 10 h p.i. both for sfGFP without and with LVA tag (Figure 7GH). With LVA labeling, however, not only the change in the intensity was detected, but also the proportion of $\mathrm{P}_{p s t}$-positive bacteria highly decreased. The overview images showed that especially in heavily loaded HeLa cells and RAW264.7 macrophages, no further sfGFP signals were visible for LVA-tagged version (Figure 7IJ). 
bioRxiv preprint doi: https://doi.org/10.1101/2020.10.23.351551; this version posted October 23, 2020. The copyright holder for this preprint (which was not certified by peer review) is the author/funder, who has granted bioRxiv a license to display the preprint in perpetuity. It is made available under aCC-BY-NC-ND 4.0 International license.

Intracellular Salmonella phosphate availability

We found that STM WT generally exhibited stronger $\mathrm{P}_{p s t}:$ :sfGFP induction in HeLa cells than in RAW264.7 macrophages. Furthermore, the percentage of $\mathrm{P}_{p s t s-\text {-induced bacteria was lower }}$

in activated RAW264.7 macrophages and in human macrophages compared to resting host

cells, or in STM $\Delta s s a V$ strain compared to STM WT. This might be explained by different

composition of compartments in distinct cells types, or by different levels of STM proliferation

affecting intracellular $\mathrm{P}_{\mathrm{i}}$ levels due to $\mathrm{P}_{\mathrm{i}}$ consumption. To investigate the influence of replication

on $\mathrm{P}_{\mathrm{i}}$ availability we infected HeLa cells or RAW264.7 macrophages and added Cotrimoxazole

to inhibit intracellular replication. In HeLa cells we observed no changes at 8 h p.i., but

significantly lower sfGFP intensity at 16 h p.i. indicating higher $\mathrm{P}_{\mathrm{i}}$ availability (Figure 8ABC).

Quantification of CFU of intracellular STM indicated lower bacterial counts in Cotrimoxazole-

treated cells at $8 \mathrm{~h}$ and 16 h p.i. (Figure 8D). No significant increase in CFU was observed,

showing that STM remained viable but restricted in proliferation. In RAW264.7 macrophages,

both the percentage and the intensity were lower at $16 \mathrm{~h}$ p.i. due to inhibition of bacterial

replication (Figure 8EFG). Cotrimoxazole-treatment also reduced CFU of STM in

macrophages, but proliferation between $8 \mathrm{~h}$ and $16 \mathrm{~h}$ p.i. was not fully ablated (Figure $8 \mathrm{H}$ ).

However, Cotrimoxazole-inhibited STM in macrophages showed a lower frequency of sfGFP-

positive cells at $16 \mathrm{~h}$ p.i., with sfGFP intensities as low as at $8 \mathrm{~h}$ p.i. We conclude that inhibition

of intracellular proliferation relieves the limitation of $\mathrm{P}_{\mathrm{i}}$ due to decreased consumption of the $\mathrm{P}_{\mathrm{i}}$ pool available for intracellular STM.

309 Finally, we manipulated phosphate availability in host cells and determined the effects on 310 intracellular STM. For this, i) additional phosphate was added to the cell culture medium to 311 increase $\mathrm{P}_{\mathrm{i}}$ uptake (Candeal, Caldas, Guillen, Levi, \& Sorribas, 2014), ii) acidification of the 312 SCV was inhibited by bafilomycin (Rathman, Sjaastad, \& Falkow, 1996), or iii) the proton 313 gradient was uncoupled by protonophore CCCP (Candeal et al., 2014). We added $\mathrm{P}_{\mathrm{i}}$ to the host 314 cells 24 h before infection, so that a higher $\mathrm{P}_{\mathrm{i}}$ level was already present in the host cells. When 315 we infected HeLa cells with STM WT, fewer bacteria showed induction of $\mathrm{P}_{\text {psts: }}:$ sfGFP (Figure 
bioRxiv preprint doi: https://doi.org/10.1101/2020.10.23.351551; this version posted October 23, 2020. The copyright holder for this preprint (which was not certified by peer review) is the author/funder, who has granted bioRxiv a license to display the preprint in perpetuity. It is made available under aCC-BY-NC-ND 4.0 International license.

Intracellular Salmonella phosphate availability

316 9ABC). In infected RAW264.7 macrophages additional $\mathrm{P}_{\mathrm{i}}$ had no effect on $\mathrm{P}_{p s t s:: s f G F P}$ expression by intracellular STM (Figure 9DEF). In contrast, the addition of bafilomycin and

318 thus blocking the acidification of the SCV increased sfGFP intensities of STM in RAW264.7

319 macrophages but not for STM in HeLa cells. Uncoupling by CCCP resulted in slightly higher

320 sfGFP intensity of STM in HeLa cells, but no changes were detected in RAW264.7

321 macrophages. In conclusion, the higher external $P_{i}$ levels affect $P_{i}$ availability of STM in HeLa

322 cell, while neutralization of the $\mathrm{pH}$ of SCV in RAW264.7 macrophages increased $\mathrm{P}_{\mathrm{i}}$ limitation,

323 which may be a consequence of reduced transport of $\mathrm{P}_{\mathrm{i}}$ into the SCV lumen, and/or higher $\mathrm{P}_{\mathrm{i}}$

324 consumption by increased STM proliferation in a more permissive compartment. 
bioRxiv preprint doi: https://doi.org/10.1101/2020.10.23.351551; this version posted October 23,2020 . The copyright holder for this preprint (which was not certified by peer review) is the author/funder, who has granted bioRxiv a license to display the preprint in perpetuity. It is made available under aCC-BY-NC-ND 4.0 International license.

Intracellular Salmonella phosphate availability

\section{Discussion}

Main phosphate transporter PstSCAB-PhoU is required for intracellular replication of STM

328 This study investigated nutrient availability for intracellular STM with focus on phosphate. $\mathrm{P}_{\mathrm{i}}$ 329 is essential for many important functions like DNA and RNA synthesis and energy metabolism.

330 We developed and applied a sensitive quantitative approach to investigate, at a single cell level, 331 the availability of $\mathrm{P}_{\mathrm{i}}$ within the intracellular environments of STM. Our study demonstrates the 332 importance of intracellular $\mathrm{P}_{\mathrm{i}}$ homeostasis for virulence of STM. Deletions of phoB, phoR, 333 phoU, or pstSCAB encoding the ABC transporter led to a reduced replication of STM in macrophages and epithelial cells. Several previous studies on intracellular STM reported upregulation of genes such as pstSCAB or phoBR (Eriksson, Lucchini, Thompson, Rhen, \& Hinton, 2003; Garcia-del Portillo et al., 1992; Hautefort et al., 2008). Deletion of pstSCAB was recently reported to attenuate systemic virulence of STM in the murine infection model (Zhang et al., 2019), and our work extends these findings to further components of the phosphate metabolism. The reduced replication of a $\triangle p h o B$ strain in RAW264.7 macrophages and a reduced systemic virulence in mice was recently reported (Jiang et al., 2020). Defect of PhoU

341 leads to constitutive expression of the Pst transporter and unphysiological accumulation of $\mathrm{P}_{\mathrm{i}}$ 342 in STM cytosol, indicating that the proper phosphate homeostasis is of critical importance. 343 Defects in phosphate metabolism also impaired virulence of other pathogens such as Shigella 344 flexneri, Yersinia spp., or E. coli, and several studies have shown that the Pho regulon is part of 345 a complex network important for bacterial virulence and stress response (Lamarche et al., 346 2008).

347 Using a dual fluorescence reporter, we measured $\mathrm{P}_{\mathrm{i}}$ availability and concentrations in distinct 348 intracellular habitats of STM. PstS is a periplasmic protein that binds $\mathrm{P}_{\mathrm{i}}$ with high affinity and 349 the promoter of $p s t S$ was repressed in culture by $\mathrm{P}_{\mathrm{i}}$ concentration above $1 \mathrm{mM}$, as described for 350 E. coli (Rosenberg, Gerdes, \& Chegwidden, 1977), while a phosphate down-shock experiment 
bioRxiv preprint doi: https://doi.org/10.1101/2020.10.23.351551; this version posted October 23, 2020. The copyright holder for this preprint (which was not certified by peer review) is the author/funder, who has granted bioRxiv a license to display the preprint in perpetuity. It is made available under aCC-BY-NC-ND 4.0 International license.

Intracellular Salmonella phosphate availability

351

352

353

354

355

356

357

358

359

360

361

362

363

364

365

366

367

368

369

370

371

372

373

374

375

376

revealed $\mathrm{P}_{\mathrm{i}}$ concentration above $100 \mu \mathrm{M}$ as repressing for PstS. Increasing expression of $\mathrm{P}_{p s t s}:$ :GFP with decreasing phosphate concentrations was reported for Shigella flexneri and in addition a very strong induction measured by concentration of $10 \mu \mathrm{M} \mathrm{P}_{\mathrm{i}}$ (Runyen-Janecky \& Payne, 2002). Using STM as reporter, we determined $P_{i}$ concentration of less than $10 \mu M$ within the SCV of HeLa cells and RAW264.7 macrophages based on the $\mathrm{P}_{p s t}$ ::sfGFP intensity. However, in the cytosol of HeLa cells, concentrations above $10 \mu \mathrm{M}$ were determined (Figure 10A). The released bacteria indicated a heterogeneous distribution and a pronounced change over time. Remarkable was the shift at 10 h p.i. in HeLa cells, where the cytosolic population became smaller in relation to the vacuolar population. At this time, the $\Delta s s a V$ strain differed from STM WT probably due reduced replication in the SCV (Hensel et al., 1998). In contrast, in RAW264.7 macrophages, strong $P_{i}$ deficiency was measured shortly after invasion. After 10

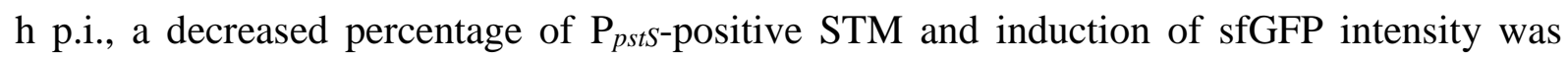
obvious. We therefore assumed that non-induced STM consisted of metabolically inactive, temporarily cytosolic, as well as dead and dormant bacteria (Helaine et al., 2014; Röder \& Hensel, 2020). In activated RAW264.7 macrophages and in primary human macrophages, both exhibiting higher antimicrobial activity (Rosenberger \& Finlay, 2002; Schwan, Huang, Hu, \& Kopecko, 2000), the induced subpopulation was smaller compared to STM WT in resting RAW264.7 macrophages, and indicated availability of less than $10 \mu \mathrm{M} \mathrm{P}_{\mathrm{i}}$.

Serovars of S. enterica cause systemic infections in humans, and macrophages are important for immunity to infection. However, what renders macrophages permissive or restrictive for survival and replication of $S$. enterica serovars is only partially understood. Human M1 macrophages (classically activated) were used here that restrict proliferation of STM (Lathrop et al., 2018). Based on analyses of fluorescence reporter strains in human macrophages, together with the results obtained by treatment with Cotrimoxazole to inhibit the intracellular replication, we conclude that consumption of and demand for $P_{i}$ was lower due to the lack of replication in these habitats, similar to an $\Delta s s a V$ strain. All these results clearly showed that $\mathrm{P}_{\mathrm{i}}$ homeostasis 
bioRxiv preprint doi: https://doi.org/10.1101/2020.10.23.351551; this version posted October 23, 2020. The copyright holder for this preprint (which was not certified by peer review) is the author/funder, who has granted bioRxiv a license to display the preprint in perpetuity. It is made available under aCC-BY-NC-ND 4.0 International license.

Intracellular Salmonella phosphate availability

allows STM to survive and replicate intracellularly. Therefore, pstSCAB-phoU seems to be the main transporter of $\mathrm{P}_{\mathrm{i}}$ and essential for replication and intracellular survival. Inhibition of such important transporter, or interference with proper sensing and regulation may be considered as new non-antibiotic strategy.

\section{Multiple effects of phosphate in regulation of virulence factors}

It is known that low levels of $\mathrm{P}_{\mathrm{i}}$ in the SCV trigger the activation of SPI2 genes (Lober, Jackel, Kaiser, \& Hensel, 2006). The translocation of effectors via the SPI2-T3SS leads to the maturation of the SCV and the formation of the SIFs (Rajashekar et al., 2008). In RAW264.7 macrophages and HeLa cells, we ascertained a correlation between SPI2 activity and $\mathrm{P}_{p s t S}$ activity. Nearly all bacteria with $\mathrm{P}_{s s a G}$ induction were also positive for $\mathrm{P}_{p s t S}$ induction (Figure $\mathrm{S}$

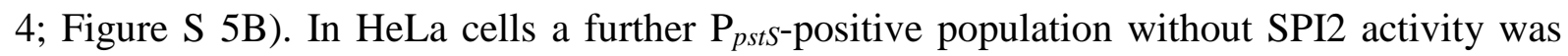
present, mainly the cytosolic subpopulation. Additionally, the PhoBR two-component system represses hilA expression under low extracellular phosphate conditions (Lucas et al., 2000). Therefore, low phosphate levels are important to control hilA expression in the intestinal environment (Baxter \& Jones, 2015). The transcriptional activator HilA controls expression of SPI1-T3SS, as well as some effector proteins for invasion. This may explain reduced invasion of the $\Delta p h o U$ strain. Deletion of phoU resulted in a missing activation of the SPI1-T3SS due to the permanent repression of hilA by phoBR. Therefore, phoBR and pstSCAB-phoU have two critical roles for virulence, i) to switch off SPI1-T3SS after invasion due to the low $\mathrm{P}_{\mathrm{i}}$ values in the intracellular space, and ii) to activate SPI2-T3SS, thus enabling the replication of STM during intracellular lifestyle.

Recently, PagR was identified as S. enterica-specific integrator of low $\mathrm{P}_{\mathrm{i}}$ and low $\mathrm{Mg}^{2+}$ levels leading to activation of expression of SPI2-T3SS genes (Jiang et al., 2020). The study proposed that $\mathrm{PhoB}$ is activated by low $\mathrm{P}_{\mathrm{i}}$, and $\mathrm{PhoQ}$ in response to low $\mathrm{Mg}^{2+}$, both activated PagR. PagR activates SlyA, and SlyA induces expression of ssrAB. Increased levels of the two-component system SsrAB then result in increased expression of genes encoding the SPI2-T3SS and cognate 
bioRxiv preprint doi: https://doi org/10.1101/2020.10.23.351551; this version posted October 23, 2020. The copyright holder for this preprint (which was not certified by peer review) is the author/funder, who has granted bioRxiv a license to display the preprint in perpetuity. It is made available under aCC-BY-NC-ND 4.0 International license.

Intracellular Salmonella phosphate availability

403

404

405

406

407

408

409

410

411

412

413

414

415

416

417

418

419

420

421

422

423

424

425

426

427

effector proteins. This cascade explains an amplification loop resulting in additional copies of SsrAB. However, the sensor SsrA also responds directly to physicochemical signals in the SCV in order to activate expression of SPI2-T3SS functions, and phosphate limitation and mildly acidic pH were identified as signals (Deiwick, Nikolaus, Erdogan, \& Hensel, 1999; Lober et al., 2006).

Another study observed that MgtC interacts with PhoR leading to activation of the Pho regulon via PhoB and increased $P_{i}$ uptake (Choi et al., 2019). Interestingly, and in contrast to our findings, inactivation of $p h o B$, or interference with MgtC-PhoR interaction resulted in decreased $P_{i}$ transport but increased proliferation in macrophages, and higher virulence in a murine model (Choi et al., 2019). These phenomena were explained by dual roles of MgtC in controlling $\mathrm{F}_{0} \mathrm{~F}_{1}$ ATPase and intracellular $\mathrm{pH}$ (Lee, Pontes, \& Groisman, 2013), and the new interaction with PhoR.

Work by Pontes and Groisman (Pontes \& Groisman, 2018) suggested a further regulatory cascade. Starvation of STM in the SCV for $\mathrm{Mg}^{2+}$ results in ribosome instability, decreased protein biosynthesis, and decreased ATP hydrolysis leading to lower levels of $\mathrm{P}_{\mathrm{i}}$ in the cytosol of STM. This situation induces the Pst transport system, despite sufficient $\mathrm{P}_{\mathrm{i}}$ availability in the extracellular space. This model also supports the function of $\mathrm{PhoR}$ as sensor for $\mathrm{P}_{\mathrm{i}}$ in the bacterial cytosol, in line with the absence of the periplasmic domain in PhoR for sensing $\mathrm{P}_{\mathrm{i}}$ in periplasm and thus extracellular milieu (Gardner \& McCleary, 2019).

Future work has to clarify the interconnected effects of extracellular and cytosolic $\mathrm{P}_{\mathrm{i}}$ concentration, transport, the $\mathrm{P}_{\mathrm{i}}$ consumption by anabolism during STM proliferation, and the effect of ATP hydrolysis. For this, STM reporter strains are useful tools, yet need to complemented by single cells sensors such as $\mathrm{P}_{\mathrm{i}}$-sensitive fluorescent proteins that directly sense phosphate levels.

STM reporter strains as tool for measuring phosphate concentrations 
bioRxiv preprint doi: https://doi.org/10.1101/2020.10.23.351551; this version posted October 23,2020 . The copyright holder for this preprint (which was not certified by peer review) is the author/funder, who has granted bioRxiv a license to display the preprint in perpetuity. It is made available under aCC-BY-NC-ND 4.0 International license.

Intracellular Salmonella phosphate availability

In further experiments, we aimed to induce specific $\mathrm{P}_{\mathrm{i}}$ changes in host cells and to measure these using STM reporter strains. Our work suggests that STM may serve as simple and sensitive tool for measuring intracellular $\mathrm{P}_{\mathrm{i}}$ concentrations. In Caco2BBe1 cells external supply of $4 \mathrm{mM} \mathrm{P} \mathrm{P}_{\mathrm{i}}$ increases phosphate uptake. The addition of CCCP reduced intracellular $\mathrm{P}_{\mathrm{i}}$ levels and Bafilomycin showed no effect in CaCo2BBe1 cells on $\mathrm{P}_{\mathrm{i}}$ uptake (Candeal et al., 2014). We observed similar results using the dual fluorescence reporter after STM infection of HeLa cells, but not of RAW264.7 macrophages. While in HeLa cells a portion of the intracellular population resides in host cell cytosol, in RAW264.7 macrophages nearly all bacteria remain within the SCV. Therefore, we assume that the addition of $4 \mathrm{mM} \mathrm{P}_{\mathrm{i}}$ or CCCP changes the cytosolic $\mathrm{P}_{\mathrm{i}}$ concentration of the host cells, but $\mathrm{P}_{\mathrm{i}}$ levels in the SCV were unaffected. In addition, Bafilomycin only showed detectable changes in RAW264.7 macrophages, maybe as consequence of the cytosolic population in HeLa cells. The cytosol of HeLa cells is neutral with pH 7-8 (Llopis, McCaffery, Miyawaki, Farquhar, \& Tsien, 1998), while the SCV acidifies from pH 6 to pH 4-5 which can be inhibited by using Bafilomycin (Rathman et al., 1996). Therefore, the lack of acidification changes the $\mathrm{P}_{\mathrm{i}}$ availability in the SCV of RAW264.7 macrophages, suggesting a neutral $\mathrm{pH}$ decrease the $\mathrm{P}_{\mathrm{i}}$ influx into the SCV/SIF-continuum.

\section{Increase of the SCV-SIF continuum enables further transport of $P_{i}$}

In vertebrates, $\mathrm{P}_{\mathrm{i}}$ homeostasis is mediated by sodium-dependent $\mathrm{P}_{\mathrm{i}}$ transporters that use the inwardly directed electrochemical gradient of $\mathrm{Na}^{+}$ions. In $\mathrm{HeLa}$ cells, the major $\mathrm{Na}^{+}-\mathrm{P}_{\mathrm{i}}$ cotransporter is PiT1 (Bon et al., 2018). Gradients are established by the $\mathrm{Na}^{+}-\mathrm{K}^{+}$-ATPase to control $\mathrm{P}_{\mathrm{i}}$ influx (Virkki, Biber, Murer, \& Forster, 2007). It is not known if specific $\mathrm{P}_{\mathrm{i}}$ transporters exist in endosomal membranes that control luminal $\mathrm{P}_{\mathrm{i}}$. Previous work by Vorwerk et al. (2015) investigated the proteome of host cell endomembranes modified by intracellular STM and identified a mitochondrial phosphate carrier protein (MCPC) (Vorwerk, Krieger, Deiwick, Hensel, \& Hansmeier, 2015) that catalyzes the transport of $\mathrm{P}_{\mathrm{i}}$ by $\mathrm{H}^{+}$cotransport into the mitochondrial matrix. Therefore, we assume that $\mathrm{P}_{\mathrm{i}}$ influx in the SCV/SIF continuum also 
bioRxiv preprint doi: $\mathrm{https}$ //doi.org/10.1101/2020.10.23.351551; this version posted October 23, 2020. The copyright holder for this preprint (which was not certified by peer review) is the author/funder, who has granted bioRxiv a license to display the preprint in perpetuity. It is made available under aCC-BY-NC-ND 4.0 International license.

Intracellular Salmonella phosphate availability

454

455

456

457

458

459

460

461

462

463

464

465

466

467

468

469

470

471

472

473

474

475

476

477 The data that support the findings of this study are available from the corresponding author

478

requires a $\mathrm{H}^{+}$or $\mathrm{Na}^{+}$gradient. Enlargement of membrane surface and lumen of the SCV-SIF continuum may lead to reduction of $\mathrm{H}^{+}$or $\mathrm{Na}^{+}$luminal concentration, thus increase the gradient resulting in increased $\mathrm{H}^{+}$and $\mathrm{P}_{\mathrm{i}}$ cotransport. Furthermore, an improved fusion with vesicles though the enlarged membrane also possible to increase $P_{i}$ transport (Liss et al., 2017). Therefore, we conclude that STM WT increases $\mathrm{P}_{\mathrm{i}}$ transport due to the enlargement of SCVSIF continuum resulting in bacteria replication. An $\Delta s s a V$ strain, without the SCV-SIF continuum, cannot replicate due to the lack of access to $\mathrm{P}_{\mathrm{i}}$ (Figure 10B).

In conclusion, we used STM as reporter to monitor, at single cell level, phosphate availability in distinct intracellular niches and host cell types. Proper $\mathrm{P}_{\mathrm{i}}$ homeostasis is critical for the intracellular lifestyle of STM and the non-redundant nature of the high affinity $\mathrm{P}_{\mathrm{i}}$ transporter may indicate a new target for therapeutic interference with systemic S. enterica infections.

\section{Acknowledgements}

This work was supported by the Deutsche Forschungsgemeinschaft by grant HE 1964/18-2 and BMBF by grant 031L0093A as part of the Infect-ERA cluster SalHostTrop. We thank Jörg Deiwick for construction of p3776, Pascal Felgner for cloning p5081, Monika Nietschke for excellent technical support and Tatjana Reuter for support by the isolation of primary human macrophages.

\section{Conflict of interest statement}

The authors declare no conflict of interest.

\section{Data availability statement} upon reasonable request. 
bioRxiv preprint doi: https://doi.org/10.1101/2020 10.23.351551; this version posted October 23, 2020. The copyright holder for this preprint (which was not certified by peer review) is the author/funder, who has granted bioRxiv a license to display the preprint in perpetuity. It is made available under aCC-BY-NC-ND 4.0 International license.

Intracellular Salmonella phosphate availability

480 Authors contributions

481 JR and MH conceived the study, JR performed experimental work, JR and MH analyzed the 482 data, JR and MH wrote the manuscript.

483 
bioRxiv preprint doi: https://doi.org/10.1101/2020.10.23.351551; this version posted October 23, 2020. The copyright holder for this preprint (which was not certified by peer review) is the author/funder, who has granted bioRxiv a license to display the preprint in perpetuity. It is made available under aCC-BY-NC-ND 4.0 International license.

Intracellular Salmonella phosphate availability

484

\section{Materials and Methods}

\section{Bacterial strains and growth conditions}

Salmonella enterica serovar Typhimurium (STM) strains NCTC 12023 (identical to ATCC 14028) and isogenic mutant strains are summarized in Table 1. STM strains were routinely cultured in Luria-Bertani (LB) broth containing $50 \mu \mathrm{g} \mathrm{x} \mathrm{ml}{ }^{-1}$ carbenicillin (Roth) if required for selection of plasmids. Bacterial cultures were routinely grown in glass test tubes at $37^{\circ} \mathrm{C}$ with aeration in a roller drum at ca. 60 rpm. For invasion of HeLa cells, fresh LB medium was inoculated 1:31 with o/n cultures of STM and incubated for $3.5 \mathrm{~h}$ with agitation in a roller drum. To test induction of reporters by inorganic phosphate $\left(\mathrm{P}_{\mathrm{i}}\right)$, PCN media was supplemented with various amounts of $\mathrm{P}_{\mathrm{i}}$ ranging from $100 \mathrm{nM}$ to $25 \mathrm{mM}$.

\section{Construction of plasmids}

Plasmids used in this work are listed in Table 2. Oligonucleotides for generation of recombinant DNA molecules were obtained from IDT and are specified in Table S1.

The promoter of pstS or apeE of STM was cloned as $300 \mathrm{bp}$ fragment upstream of the translational start site of pstS or apeE using $1 \mathrm{f}-\mathrm{P}_{p s t}$ and $1 \mathrm{r}-\mathrm{P}_{p s t S}$ or $1 \mathrm{f}-a p e E^{-} \mathrm{p} 4889$ and $1 \mathrm{r}-a p e E^{-}$ p4889 for amplification of the insert. Primers Vf-p4889 and Vr-p4889 were used for amplification of vector p4889, and fragments were fused by Gibson assembly (GA) to generate p5007 or p5081. Dual fluorescence reporter p5007 and p5081 harbor $\mathrm{P}_{\text {EM7::DsRed for }}$ constitutive expression of DsRed, and $\mathrm{P}_{p s t}:$ :sfGFP or $\mathrm{P}_{\text {apeE }}:$ sfGFP for sfGFP expression.

Plasmid pM937 was used to generate p3775 by insertion of transcriptional terminators and

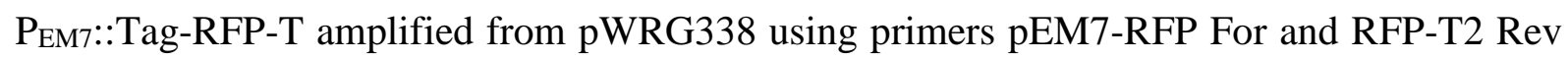
and cloning as NotI/SacI fragment. The eGFP gene in p3775 was replaced by sfGFP obtained as XhoI/BamHI fragment from pWRG167 to generate p3776.

The promoter of ssaG was cloned as 320 bp fragment upstream of the translational start site of ssaG. EM7 was replaced by $\mathrm{P}_{\text {ssaG }}$ using $\mathrm{GA}$ to create $\mathrm{p} 5457$ with primers Vf-p4889-exEM7 and 
bioRxiv preprint doi: https://doi org/10.1101/2020.10.23.351551; this version posted October 23, 2020. The copyright holder for this preprint (which was not certified by peer review) is the author/funder, who has granted bioRxiv a license to display the preprint in perpetuity. It is made available under aCC-BY-NC-ND 4.0 International license.

Intracellular Salmonella phosphate availability

Vr-p4889-exEM7 for amplification of vector p5007, and 1f-PssaG-p4889 and 1r-PssaG-p4889 for amplification of the insert from p3776. The promoter of $u h p T$ was cloned as $251 \mathrm{bp}$ fragment

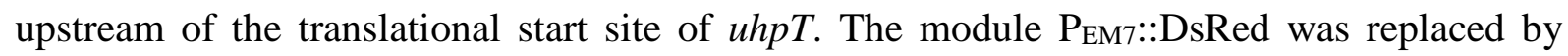

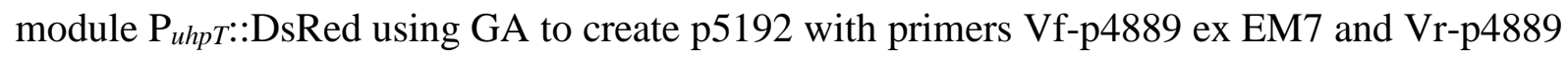
ex EM7 for amplification of vector p5007, and 1f p5407 PuhpT and 1r-p4507 Dsred for amplification of the insert from p5407.

For destabilization of sfGFP, the LVA tag according to BioBricks (AGGCCTGCTGCAAACGACGAAAACTACGCTTTAGTAGCT) was fused to the Cterminus to sfGFP via SDM with primers p4889-LVA SDM For and sfGFP-LVA Rev to create p5440.

\section{Cell lines and cultivation}

Human epithelial cell line HeLa were maintained in DMEM containing $4.5 \mathrm{~g} \mathrm{x} \mathrm{l}^{-1}$ glucose, 4 mM L-glutamine and sodium pyruvate (Biochrom) supplemented with $10 \%$ FCS in an atmosphere of $5 \% \mathrm{CO}_{2}$ and $90 \%$ humidity at $37{ }^{\circ} \mathrm{C}$. The murine macrophage cell line RAW264.7 (ATCC no. TIB-71) were cultured in DMEM containing $4.5 \mathrm{~g} \mathrm{x} \mathrm{l}^{-1}$ glucose and 4 mM stable glutamine (Biochrom) supplemented with 6\% FCS.

\section{Preparation of primary human macrophages}

Primary human macrophages were prepared from buffy coat from pooled blood samples of anonymous donors (obtained from the Deutsches Rotes Kreuz) as described in Bonifacino et al. Page 2/6 - 2/9 (Bonifacino, Dasso, B., Lippincott-Schwartz, \& Yamada, 2004). Preparation of lymphocytes by Ficoll-Hypaque gradient was performed as described, alternatively to whole blood, buffy coat was mixed 1+1 with PBS. For differentiation into monocytes/macrophages, the isolated lymphocytes were thawed, seeded and maintained in RPMI-1640 (Biochrom), supplemented with 20\% FCS and $2.5 \mathrm{ng} \mathrm{x} \mathrm{ml}^{-1}$ GM-CSF (Peprotech). After 5-7 days, the purity 
bioRxiv preprint doi: $h$ ttps://doi.org/10.1101/2020.10.23.351551; this version posted October 23, 2020. The copyright holder for this preprint (which was not certified by peer review) is the author/funder, who has granted bioRxiv a license to display the preprint in perpetuity. It is made available under aCC-BY-NC-ND 4.0 International license.

Intracellular Salmonella phosphate availability

533

534

535

536

537

538

539

540

541

542

543

544

545

546

547

548

549

550

551

552

553

554

555

556

557

of the monocyte/macrophage population was checked by staining with FITC anti-human CD14 antibody (BioLegend) and FC, and subsequently used for infection.

\section{Infection of host cells}

Host cell infections were performed as previously described (Rajashekar et al., 2008). Briefly, RAW246.7 macrophages and human macrophages were infected with o/n cultures, and HeLa cells were infected with 3.5 h subcultures of STM at multiplicity of infection (MOI) of 5 or 25. Infected cells were centrifuged at $500 \mathrm{x}$ g for $5 \mathrm{~min}$ to synchronize infection, incubated for 25 min at $37{ }^{\circ} \mathrm{C}$ in an atmosphere of $5 \% \mathrm{CO}_{2}$, before extracellular bacteria were removed by washing thrice with PBS. Subsequently, host cells were maintained in growth media containing $100 \mu \mathrm{g} \mathrm{x} \mathrm{ml}^{-1}$ gentamicin for $1 \mathrm{~h}$, followed by media containing $10 \mu \mathrm{g} \mathrm{x} \mathrm{ml} \mathrm{l}^{-1}$ for remaining time of incubation.

CI assay

Competitive Index assay was performed as previously described (Segura, Casadesus, \& RamosMorales, 2004). Briefly, HeLa cells or RAW264.7 macrophages were seeded in surface-treated 24-well plates (Faust) and grown to $80 \%$ confluency at the day of infection. WT without antibiotic resistance and mutant strains harboring the aph cassette were separately grown in LB

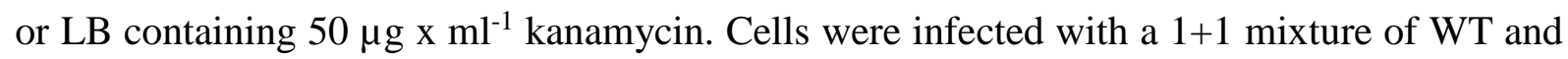
mutant strain at an overall MOI of 1 for 25 min. Non-invaded bacteria were killed using media containing $100 \mu \mathrm{g} \mathrm{x} \mathrm{ml}{ }^{-1}$ gentamicin for $1 \mathrm{~h}$ and replaced by media containing $10 \mu \mathrm{g} \mathrm{x} \mathrm{ml}{ }^{-1}$ gentamicin for further incubation. The numbers of viable intracellular bacteria were determined $1 \mathrm{~h}$ and $16 \mathrm{~h}$ p.i. by plating onto LB agar with and without kanamycin (AppliChem). The CI for bacterial survival is defined as the ratio of $\mathrm{x}$-fold replication of WT to mutant strain for $1 \mathrm{~h}$.

Pulse-chase with fluid phase markers

For tracing the endocytic pathway, fluid phase markers were used. HeLa cells and RAW264.7 macrophages were incubated with $100 \mu \mathrm{g} \mathrm{x} \mathrm{ml} \mathrm{m}^{-1}$ AlexaFluor 647-conjugated dextran, 
bioRxiv preprint doi: $\mathrm{https}$ //doi.org/10.1101/2020.10.23.351551; this version posted October 23, 2020. The copyright holder for this preprint (which was not certified by peer review) is the author/funder, who has granted bioRxiv a license to display the preprint in perpetuity. It is made available under aCC-BY-NC-ND 4.0 International license.

Intracellular Salmonella phosphate availability

558 (molecular weight 10,000, Molecular Probes) o/n, washed, and incubated with dextran-free

559 media. Cells were infected for $25 \mathrm{~min}$, incubated $1 \mathrm{~h}$ with $100 \mu \mathrm{g} \mathrm{x} \mathrm{ml}{ }^{-1}$ gentamicin, cultivated

$56015 \mathrm{~h}$ in growth media with a decreased gentamicin concentration of $10 \mu \mathrm{g} \mathrm{x} \mathrm{ml}^{-1}$ and processed

561 for imaging.

562 Live cell imaging

563 HeLa cells and RAW267.4 macrophages cultured in 8-well chamber slides were infected at

564 MOI of 5. The infection was performed as described above and $16 \mathrm{~h}$ p.i., the medium was

565 replaced by Imaging Medium supplemented with $10 \mu \mathrm{g} \mathrm{x} \mathrm{ml}{ }^{-1}$ gentamicin. Live cell imaging

566 was carried out by CLSM on a Leica SP5 with an environmental incubation chamber

567 maintaining a humidified atmosphere of $5 \% \mathrm{CO}_{2}$.

568 Quantification by flow cytometry analyses

569 HeLa cells and RAW264.7 macrophages were infected at MOI of 5 for 25 min. At various time

570 points from 2 to 24 h p.i., cells were lysed with $0.1 \%$ Triton X-100 and fixed with 3\% PFA for

571 subsequent FC analyses using the Attune NxT Cytometer (Thermo Fischer). Experiments were

572 performed in triplicates at least three times. Data were analyzed with Attune NxT 2.5. Statistical

573 analyses were performed using One-Way Anova Bonferroni using SigmaPlot 13 (Systat

574 Software).

575 
bioRxiv preprint doi: https://doi.org/10.1101/2020.10.23.351551; this version posted October 23,2020 . The copyright holder for this preprint (which was not certified by peer review) is the author/funder, who has granted bioRxiv a license to display the preprint in perpetuity. It is made available under aCC-BY-NC-ND 4.0 International license.

Intracellular Salmonella phosphate availability

\section{References}

Andersen, J. B., Sternberg, C., Poulsen, L. K., Bjorn, S. P., Givskov, M., \& Molin, S. (1998). New unstable variants of green fluorescent protein for studies of transient gene expression in bacteria. Appl Environ Microbiol, 64(6), 2240-2246. Retrieved from https://www.ncbi.nlm.nih.gov/pubmed/9603842

Baxter, M. A., \& Jones, B. D. (2015). Two-component regulators control hilA expression by controlling fimZ and hilE expression within Salmonella enterica serovar Typhimurium. Infect Immun, 83(3), 978-985. doi:10.1128/IAI.02506-14

Beuzon, C. R., Meresse, S., Unsworth, K. E., Ruiz-Albert, J., Garvis, S., Waterman, S. R., . . . Holden, D. W. (2000). Salmonella maintains the integrity of its intracellular vacuole through the action of SifA. EMBO J, 19(13), 3235-3249. doi:10.1093/emboj/19.13.3235

Bon, N., Couasnay, G., Bourgine, A., Sourice, S., Beck-Cormier, S., Guicheux, J., \& Beck, L. (2018). Phosphate $\left(\mathrm{P}_{\mathrm{i}}\right)$-regulated heterodimerization of the high-affinity sodiumdependent $\mathrm{P}_{\mathrm{i}}$ transporters PiT1/Slc20a1 and PiT2/Slc20a2 underlies extracellular $\mathrm{P}_{\mathrm{i}}$ sensing independently of $\mathrm{P}_{\mathrm{i}}$ uptake. $J$ Biol Chem, 293(6), 2102-2114. doi:10.1074/jbc.M117.807339

Bonifacino, J. S., Dasso, M., B., H. J., Lippincott-Schwartz, J., \& Yamada, K. M. (2004). Short Protocols in Cell Biology. Wiley ISBN: 0471483397.

Brumell, J. H., Rosenberger, C. M., Gotto, G. T., Marcus, S. L., \& Finlay, B. B. (2001). SifA permits survival and replication of Salmonella Typhimurium in murine macrophages. Cell Microbiol, 3(2), 75-84. doi:10.1046/j.1462-5822.2001.00087.x

Brumell, J. H., Tang, P., Mills, S. D., \& Finlay, B. B. (2001). Characterization of Salmonellainduced filaments (Sifs) reveals a delayed interaction between Salmonella-containing vacuoles and late endocytic compartments. Traffic, 2(9), 643-653. doi:10.1034/j.16000854.2001.20907.x

Bumann, D., \& Cunrath, O. (2017). Heterogeneity of Salmonella-host interactions in infected host tissues. Curr Opin Microbiol, 39, 57-63. doi:10.1016/j.mib.2017.09.008

Candeal, E., Caldas, Y. A., Guillen, N., Levi, M., \& Sorribas, V. (2014). Na ${ }^{+}$-independent phosphate transport in Caco2BBE cells. Am J Physiol Cell Physiol, 307(12), C11131122. doi:10.1152/ajpcell.00251.2014

Chakravortty, D., Hansen-Wester, I., \& Hensel, M. (2002). Salmonella pathogenicity island 2 mediates protection of intracellular Salmonella from reactive nitrogen intermediates. $J$. Exp. Med., 195(9), 1155-1166. Retrieved from 11994420

http://pubmedcentralcanada.ca/picrender.cgi?artid=1258717\&blobtype=pdf

Choi, S., Choi, E., Cho, Y. J., Nam, D., Lee, J., \& Lee, E. J. (2019). The Salmonella virulence protein MgtC promotes phosphate uptake inside macrophages. Nat Commun, 10(1), 3326. doi:10.1038/s41467-019-11318-2

Conlin, C. A., Tan, S. L., Hu, H., \& Segar, T. (2001). The apeE gene of Salmonella enterica serovar Typhimurium is induced by phosphate limitation and regulated by phoBR. $J$ Bacteriol, 183(5), 1784-1786. doi:10.1128/JB.183.5.1784-1786.2001

Deiwick, J., \& Hensel, M. (1999). Regulation of virulence genes by environmental signals in Salmonella Typhimurium. Electrophoresis, 20(4-5), 813-817. doi:10.1002/(SICI)15222683(19990101)20:4/5<813::AID-ELPS813>3.0.CO;2-Q

Deiwick, J., Nikolaus, T., Erdogan, S., \& Hensel, M. (1999). Environmental regulation of Salmonella pathogenicity island 2 gene expression. Mol Microbiol, 31(6), 1759-1773. doi:10.1046/j.1365-2958.1999.01312.x

Drecktrah, D., Knodler, L. A., Howe, D., \& Steele-Mortimer, O. (2007). Salmonella trafficking is defined by continuous dynamic interactions with the endolysosomal system. Traffic, 8(3), 212-225. doi:10.1111/j.1600-0854.2006.00529.x 
bioRxiv preprint doi: https://doi.org/10.1101/2020.10.23.351551; this version posted October 23,2020 . The copyright holder for this preprint (which was not certified by peer review) is the author/funder, who has granted bioRxiv a license to display the preprint in perpetuity. It is made available under aCC-BY-NC-ND 4.0 International license.

Intracellular Salmonella phosphate availability

625

626

627

628

629

630

631

632

633

634

635

636

637

638

639

640

641

642

643

644

645

646

647

648

649

650

651

652

653

654

655

656

657

658

659

660

661

662

663

664

665

666

667

668

669

670

671

672

673

674

675

Eriksson, S., Lucchini, S., Thompson, A., Rhen, M., \& Hinton, J. C. (2003). Unravelling the biology of macrophage infection by gene expression profiling of intracellular Salmonella enterica. Mol Microbiol, 47(1), 103-118. doi:10.1046/j.13652958.2003.03313.x

Figueira, R., \& Holden, D. W. (2012). Functions of the Salmonella pathogenicity island 2 (SPI2) type III secretion system effectors. Microbiology, 158(Pt 5), 1147-1161. doi:10.1099/mic.0.058115-0

Garcia-del Portillo, F., Foster, J. W., Maguire, M. E., \& Finlay, B. B. (1992). Characterization of the micro-environment of Salmonella Typhimurium-containing vacuoles within MDCK epithelial cells. Mol Microbiol, 6(22), 3289-3297. doi:10.1111/j.13652958.1992.tb02197.x

Gardner, S. G., Johns, K. D., Tanner, R., \& McCleary, W. R. (2014). The PhoU protein from Escherichia coli interacts with PhoR, PstB, and metals to form a phosphate-signaling complex at the membrane. J Bacteriol, 196(9), 1741-1752. doi:10.1128/JB.00029-14

Gardner, S. G., \& McCleary, W. R. (2019). Control of the phoBR Regulon in Escherichia coli. EcoSal Plus, 8(2). doi:10.1128/ecosalplus.ESP-0006-2019

Hapfelmeier, S., Stecher, B., Barthel, M., Kremer, M., Muller, A. J., Heikenwalder, M., . . . Hardt, W. D. (2005). The Salmonella pathogenicity island (SPI)-2 and SPI-1 type III secretion systems allow Salmonella serovar Typhimurium to trigger colitis via MyD88dependent and MyD88-independent mechanisms. J Immunol, 174(3), 1675-1685. doi:10.4049/jimmunol.174.3.1675

Haraga, A., Ohlson, M. B., \& Miller, S. I. (2008). Salmonellae interplay with host cells. Nat Rev Microbiol, 6(1), 53-66. doi:10.1038/nrmicro1788

Hautefort, I., Thompson, A., Eriksson-Ygberg, S., Parker, M. L., Lucchini, S., Danino, V., .. . Hinton, J. C. (2008). During infection of epithelial cells Salmonella enterica serovar Typhimurium undergoes a time-dependent transcriptional adaptation that results in simultaneous expression of three type 3 secretion systems. Cell Microbiol, 10(4), 958984. doi:10.1111/j.1462-5822.2007.01099.x

Helaine, S., Cheverton, A. M., Watson, K. G., Faure, L. M., Matthews, S. A., \& Holden, D. W. (2014). Internalization of Salmonella by macrophages induces formation of nonreplicating persisters. Science, 343(6167), 204-208. doi:10.1126/science.1244705

Hensel, M., Shea, J. E., Gleeson, C., Jones, M. D., Dalton, E., \& Holden, D. W. (1995). Simultaneous identification of bacterial virulence genes by negative selection. Science, 269(5222), 400-403. doi:10.1126/science.7618105

Hensel, M., Shea, J. E., Waterman, S. R., Mundy, R., Nikolaus, T., Banks, G., . . . Holden, D. W. (1998). Genes encoding putative effector proteins of the type III secretion system of Salmonella pathogenicity island 2 are required for bacterial virulence and proliferation in macrophages. Mol Microbiol, 30(1), 163-174. Retrieved from http://www.ncbi.nlm.nih.gov/pubmed/9786193

Hsieh, Y. J., \& Wanner, B. L. (2010). Global regulation by the seven-component $\mathrm{P}_{\mathrm{i}}$ signaling system. Curr Opin Microbiol, 13(2), 198-203. doi:10.1016/j.mib.2010.01.014

Jiang, L., Wang, P., Li, X., Lv, R., Wang, L., Yang, B., . . . Liu, B. (2020). PagR mediates the precise regulation of Salmonella pathogenicity island 2 gene expression in response to magnesium and phosphate signals in Salmonella Typhimurium. Cell Microbiol, 22(2), e13125. doi:10.1111/cmi.13125

Knodler, L. A. (2015). Salmonella enterica: living a double life in epithelial cells. Curr Opin Microbiol, 23, 23-31. doi:10.1016/j.mib.2014.10.010

Knodler, L. A., Vallance, B. A., Celli, J., Winfree, S., Hansen, B., Montero, M., \& SteeleMortimer, O. (2010). Dissemination of invasive Salmonella via bacterial-induced extrusion of mucosal epithelia. Proc Natl Acad Sci U S A, 107(41), 17733-17738. doi:10.1073/pnas.1006098107 
bioRxiv preprint doi: https://doi.org/10.1101/2020.10.23.351551; this version posted October 23,2020 . The copyright holder for this preprint (which was not certified by peer review) is the author/funder, who has granted bioRxiv a license to display the preprint in perpetuity. It is made available under aCC-BY-NC-ND 4.0 International license.

Intracellular Salmonella phosphate availability

676

677

678

679

680

681

682

683

684

685

686

687

688

689

690

691

692

693

694

695

696

697

698

699

700

701

702

703

704

705

706

707

708

709

710

711

712

713

714

715

716

717

718

719

720

721

722

723

724

Lamarche, M. G., Wanner, B. L., Crepin, S., \& Harel, J. (2008). The phosphate regulon and bacterial virulence: a regulatory network connecting phosphate homeostasis and pathogenesis. FEMS Microbiol Rev, 32(3), 461-473. doi:10.1111/j.15746976.2008.00101.x

Lathrop, S. K., Cooper, K. G., Binder, K. A., Starr, T., Mampilli, V., Detweiler, C. S., \& SteeleMortimer, O. (2018). Salmonella Typhimurium Infection of Human Monocyte-Derived Macrophages. Curr Protoc Microbiol, 50(1), e56. doi:10.1002/cpmc.56

Lee, E. J., Pontes, M. H., \& Groisman, E. A. (2013). A bacterial virulence protein promotes pathogenicity by inhibiting the bacterium's own $\mathrm{F}_{1} \mathrm{~F}_{0}$ ATP synthase. Cell, 154(1), 146156. doi:10.1016/j.cell.2013.06.004

Lim, S., Kim, B., Choi, H. S., Lee, Y., \& Ryu, S. (2006). Fis is required for proper regulation of ssaG expression in Salmonella enterica serovar Typhimurium. Microb Pathog, 41(1), 33-42. doi:10.1016/j.micpath.2006.03.005

Liss, V., Swart, A. L., Kehl, A., Hermanns, N., Zhang, Y., Chikkaballi, D., . . . Hensel, M. (2017). Salmonella enterica remodels the host cell endosomal system for efficient intravacuolar nutrition. Cell Host Microbe, 21(3), 390-402. doi:10.1016/j.chom.2017.02.005

Llopis, J., McCaffery, J. M., Miyawaki, A., Farquhar, M. G., \& Tsien, R. Y. (1998). Measurement of cytosolic, mitochondrial, and Golgi $\mathrm{pH}$ in single living cells with green fluorescent proteins. Proc Natl Acad Sci $U$ S A, 95(12), 6803-6808. doi:10.1073/pnas.95.12.6803

Lober, S., Jackel, D., Kaiser, N., \& Hensel, M. (2006). Regulation of Salmonella pathogenicity island 2 genes by independent environmental signals. Int J Med Microbiol, 296(7), 435447. doi:10.1016/j.ijmm.2006.05.001

Lucas, R. L., Lostroh, C. P., DiRusso, C. C., Spector, M. P., Wanner, B. L., \& Lee, C. A. (2000). Multiple factors independently regulate hilA and invasion gene expression in Salmonella enterica serovar typhimurium. J Bacteriol, 182(7), 1872-1882. doi:10.1128/jb.182.7.1872-1882.2000

Noster, J., Chao, T. C., Sander, N., Schulte, M., Reuter, T., Hansmeier, N., \& Hensel, M. (2019). Proteomics of intracellular Salmonella enterica reveals roles of Salmonella pathogenicity island 2 in metabolism and antioxidant defense. PLoS Pathog, 15(4), e1007741. doi:10.1371/journal.ppat.1007741

Pedelacq, J. D., Cabantous, S., Tran, T., Terwilliger, T. C., \& Waldo, G. S. (2006). Engineering and characterization of a superfolder green fluorescent protein. Nat Biotechnol, 24(1), 79-88. doi:10.1038/nbt1172

Pontes, M. H., \& Groisman, E. A. (2018). Protein synthesis controls phosphate homeostasis. Genes Dev, 32(1), 79-92. doi:10.1101/gad.309245.117

Rajashekar, R., Liebl, D., Seitz, A., \& Hensel, M. (2008). Dynamic remodeling of the endosomal system during formation of Salmonella-induced filaments by intracellular Salmonella enterica. Traffic, 9(12), 2100-2116. doi:10.1111/j.1600-0854.2008.00821.x

Rathman, M., Sjaastad, M. D., \& Falkow, S. (1996). Acidification of phagosomes containing Salmonella Typhimurium in murine macrophages. Infect Immun, 64(7), 2765-2773. Retrieved from https://www.ncbi.nlm.nih.gov/pubmed/8698506

Röder, J., \& Hensel, M. (2020). Presence of SopE and mode of infection result in increased Salmonella-containing vacuole damage and cytosolic release during host cell infection by Salmonella enterica. Cell Microbiol, 22(5), e13155. doi:10.1111/cmi.13155

Rosenberg, H., Gerdes, R. G., \& Chegwidden, K. (1977).

Two systems for the uptake of phosphate in Escherichia coli. J Bacteriol, 131(2), 505-511. Retrieved from https://www.ncbi.nlm.nih.gov/pubmed/328484 
bioRxiv preprint doi: https://doi.org/10.1101/2020.10.23.351551; this version posted October 23, 2020. The copyright holder for this preprint (which was not certified by peer review) is the author/funder, who has granted bioRxiv a license to display the preprint in perpetuity. It is made available under aCC-BY-NC-ND 4.0 International license.

Intracellular Salmonella phosphate availability

Rosenberger, C. M., \& Finlay, B. B. (2002). Macrophages inhibit Salmonella Typhimurium replication through MEK/ERK kinase and phagocyte NADPH oxidase activities. J Biol Chem, 277(21), 18753-18762. doi:10.1074/jbc.M110649200

Runyen-Janecky, L. J., \& Payne, S. M. (2002). Identification of chromosomal Shigella flexneri genes induced by the eukaryotic intracellular environment. Infect Immun, 70(8), 43794388. doi:10.1128/iai.70.8.4379-4388.2002

Schwan, W. R., Huang, X. Z., Hu, L., \& Kopecko, D. J. (2000). Differential bacterial survival, replication, and apoptosis-inducing ability of Salmonella serovars within human and murine macrophages. Infect Immun, 68(3), 1005-1013. doi:10.1128/iai.68.3.10051013.2000

Segura, I., Casadesus, J., \& Ramos-Morales, F. (2004). Use of mixed infections to study cell invasion and intracellular proliferation of Salmonella enterica in eukaryotic cell cultures. J Microbiol Methods, 56(1), 83-91. doi:10.1016/j.mimet.2003.09.004

Spierings, G., Elders, R., van Lith, B., Hofstra, H., \& Tommassen, J. (1992). Characterization of the Salmonella Typhimurium phoE gene and development of Salmonella-specific DNA probes. Gene, 122(1), 45-52. doi:10.1016/0378-1119(92)90030-s

Stein, M. A., Leung, K. Y., Zwick, M., Garcia-del Portillo, F., \& Finlay, B. B. (1996). Identification of a Salmonella virulence gene required for formation of filamentous structures containing lysosomal membrane glycoproteins within epithelial cells. Mol Microbiol, 20(1), 151-164. doi:10.1111/j.1365-2958.1996.tb02497.x

Virkki, L. V., Biber, J., Murer, H., \& Forster, I. C. (2007). Phosphate transporters: a tale of two solute carrier families. Am J Physiol Renal Physiol, 293(3), F643-654. doi:10.1152/ajprenal.00228.2007

Vorwerk, S., Krieger, V., Deiwick, J., Hensel, M., \& Hansmeier, N. (2015). Proteomes of host cell membranes modified by intracellular activities of Salmonella enterica. Mol Cell Proteomics, 14(1), 81-92. doi:10.1074/mcp.M114.041145

Wanner, B. L. (1996). Signal transduction in the control of phosphate-regulated genes of Escherichia coli. Kidney Int, 49(4), 964-967. doi:10.1038/ki.1996.136

Zhang, H., Song, X., Wang, P., Lv, R., Ma, S., \& Jiang, L. (2019). YaeB, Expressed in Response to the Acidic $\mathrm{pH}$ in Macrophages, Promotes Intracellular Replication and Virulence of Salmonella Typhimurium. Int J Mol Sci, 20(18). doi:10.3390/ijms20184339 
Intracellular Salmonella phosphate availability

\section{Tables}

759 Table 1. Salmonella enterica serovar Typhimurium strains used in this study reference

761

NCTC 12023

762

MvP503

$\Delta s i f A:: F R T$

$\Delta s s a V:: a p h$

$\Delta s s a V:: F R T$

$\Delta p h o U:: a p h$

$\Delta p h o U:: F R T$

$\Delta p h o E:: a p h$

$\Delta p h o E:: F R T$

$\Delta p h o B:: a p h$

$\Delta p h o B:: F R T$

$\Delta p h o R:: a p h$

$\Delta p h o R:: F R T$

$\triangle p s t S C A B:: a p h$

$\Delta p s t S C A B:: F R T$

$775 \quad$ MvP2898
Lab collection

(Chakravortty, Hansen-Wester,

$776 *$ all mutant strains are isogenic to STM NCTC 12023

777 Table 2. Plasmids used in this study

relevant characteristics *

$\mathrm{P}_{\text {ssaG: }}: \mathrm{eGFP}$

P EM7::TagRFP-T $_{\text {ssaG::eGFP }}$

$\mathrm{P}_{\text {EM7::TagRFP-T }} \mathrm{P}_{s s a G}:$ :sfGFP

$\mathrm{P}_{\text {EM7::DsRed }} \mathrm{P}_{\text {uhpT::sfGFP }}$
(Noster et al., 2019)

(Noster et al., 2019)

this study

this study

this study

this study

this study

this study

this study

this study

this study

this study
$779 \quad$ pM937

$780 \quad$ p3775

$781 \quad$ p3776

782 reference

(Hapfelmeier et al., 2005)

this study

this study

(Röder \& Hensel, 2020) 
bioRxiv preprint doi: https://doi.org/10.1101/2020.10.23.351551; this version posted October 23, 2020. The copyright holder for this preprint (which was not certified by peer review) is the author/funder, who has granted bioRxiv a license to display the preprint in perpetuity. It is made available under aCC-BY-NC-ND 4.0 International license.

Intracellular Salmonella phosphate availability

$783 \quad \mathrm{p} 5007$

$\mathrm{P}_{\text {EM7 }}:$ :DsRed $\mathrm{P}_{p s t}:$ :sfGFP

this study

$784 \quad \mathrm{p} 5081$

$\mathrm{P}_{\mathrm{EM} 7}:$ :DsRed $\mathrm{P}_{\text {apeE }}:$ sfGFP

this study

$785 \quad \mathrm{p} 5192$

$\mathrm{P}_{\text {uhpT::DsRed }} \mathrm{P}_{p s t}::$ :SfGFP

this study

$786 \quad \mathrm{p} 5440$

$\mathrm{P}_{\text {EM7::DsRed }} \mathrm{P}_{p s t}:$ ::sfGFP::LVA this study

$787 \quad \mathrm{p} 5457$

$\mathrm{P}_{s s a G}:$ DsRed $\mathrm{P}_{p s t}:$ :sfGFP

this study

$788 *$ all plasmids confer resistance to ampicillin

789 
Intracellular Salmonella phosphate availability

\section{Figure Legends}

A HeLa cells

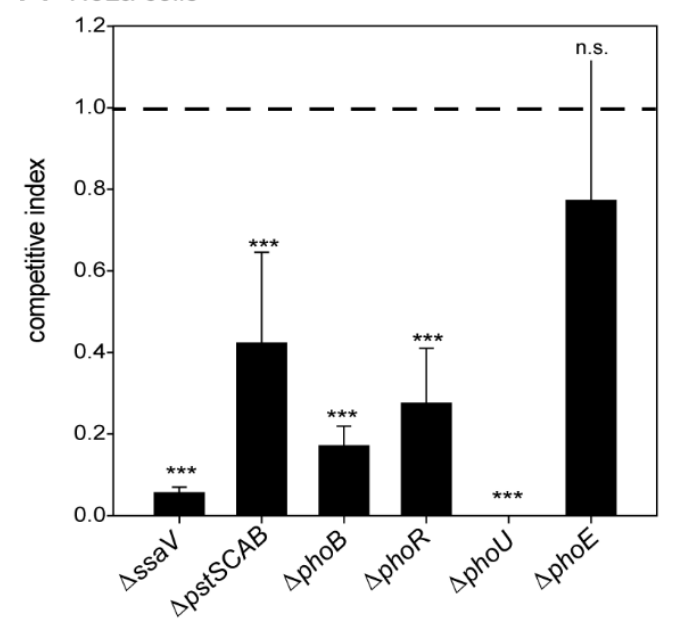

B RAW264.7 $\varphi$

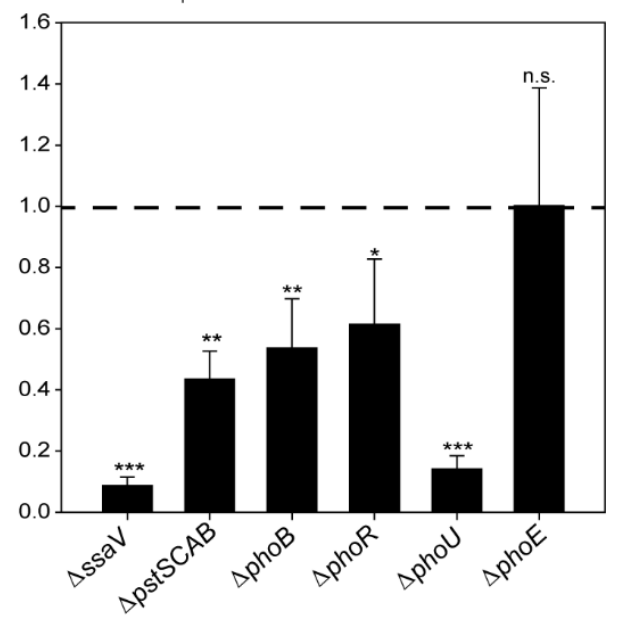

Figure 1. Role of phosphate transport systems for intracellular proliferation of STM.

793 Competitive index (CI) assays for proliferation of STM strains in HeLa cells (A), or RAW264.7 794 macrophages (B). Cells were co-infected with STM WT in combination with mutant strains defective in ssaV, pstSCAB, phoB, phoR, phoU, or phoE at a total multiplicity of infection (MOI) of 1. Intracellular proliferation was determined as the ratio of CFU at $16 \mathrm{~h}$ p.i. to $\mathrm{CFU}$ at $1 \mathrm{~h}$ p.i. and CI of replication of WT versus mutant strain was calculated. A CI of 1.0 (dashed line) indicates identical intracellular proliferation of both strains, a CI lower than 1.0 indicates attenuated proliferation of the mutant strain. Shown are mean values and standard deviations of three biological replicates, each consisting of three technical replicates. Statistical analyses were performed by one-way ANOVA in comparison to STM WT and are expressed as: n.s., not significant; *, $\mathrm{p}<0.05$; **, $\mathrm{p}<0.01$; ***, $\mathrm{p}<0.001$. 
Intracellular Salmonella phosphate availability

A

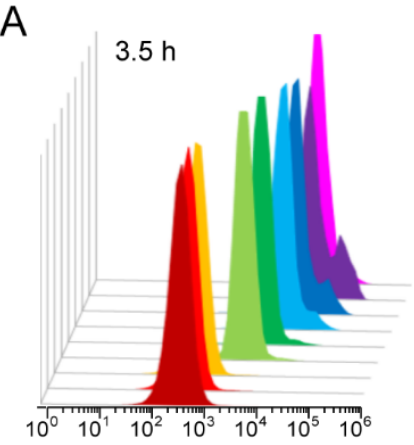

D

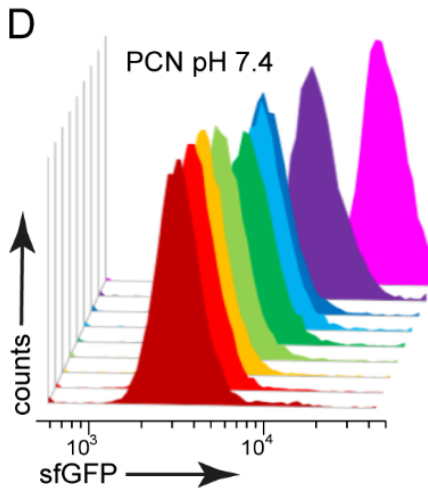

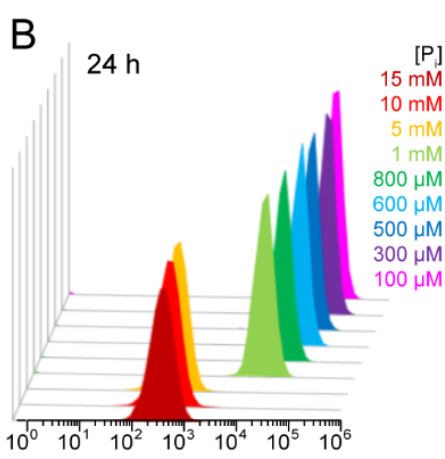

$\mathrm{E}$
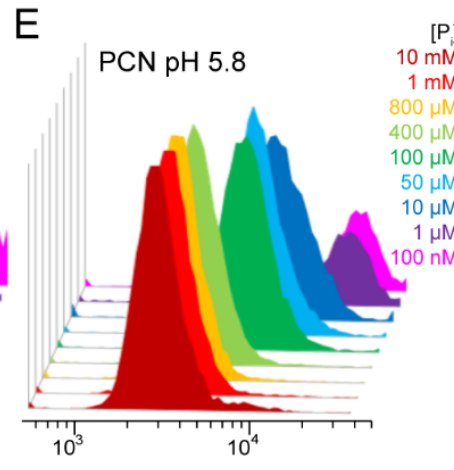

804

805

806

807

808

809

810

811

812

813

814

815

816

817

818

819

820

Figure 2. A dual fluorescence reporter for measuring the presence of phosphate. STM

harboring p5007 for constitutive expression of DsRed, and sfGFP under control of $\mathrm{P}_{p s t S}$ were cultured in PCN minimal medium with various amounts of $\mathrm{P}_{\mathrm{i}}$. Induction of $\mathrm{P}_{\text {psts::sfGFP in vitro }}$ was determined by flow cytometry (FC). A, B, C) STM WT [p5007] was grown overnight (o/n) in PCN containing 25 mM P $\mathrm{P}_{\mathrm{i}}$ (PCN (25)), $\mathrm{pH} 7.4$ and then subcultured 1:31 in PCN, pH 7.4 with various concentrations of $\mathrm{P}_{\mathrm{i}}$ as indicated. Samples were collected after $3.5 \mathrm{~h}$ (A, C black line) or $24 \mathrm{~h}$ (B, C red line) and X-means of sfGFP intensity of $\mathrm{P}_{p s t S}$-induced bacteria was determined by FC (C). D, E, F) STM WT [p5007] was grown o/n in PCN (25) pH 7.4, diluted 1:100 in PCN (1), pH 7.4 or PCN (1), pH 5.8, and subcultured to $\mathrm{OD}_{600}$ 0.5-0.7. These subcultures were used to inoculate PCN media adjusted to pH 7.4 (D, F black line) or 5.8 (E, $\mathrm{F}$, red line) with various concentrations of $\mathrm{P}_{\mathrm{i}}$ as indicated, and culture was continued for $1 \mathrm{~h}$, and X-means of sfGFP intensities were determined (F). sfGFP intensities above $10^{4} \mathrm{RFI}$ indicate $\mathrm{P}_{\mathrm{i}}$ concentrations lower than $10 \mu \mathrm{M}$. sfGFP intensities of $\mathrm{P}_{p s t s}$-positive bacteria of a representative experiment are shown. 
bioRxiv preprint doi: https://doi.org/10.1101/2020.10.23.351551; this version posted October 23, 2020. The copyright holder for this preprint (which was not certified by peer review) is the author/funder, who has granted bioRxiv a license to display the preprint in perpetuity. It is made available under aCC-BY-NC-ND 4.0 International license.

Intracellular Salmonella phosphate availability
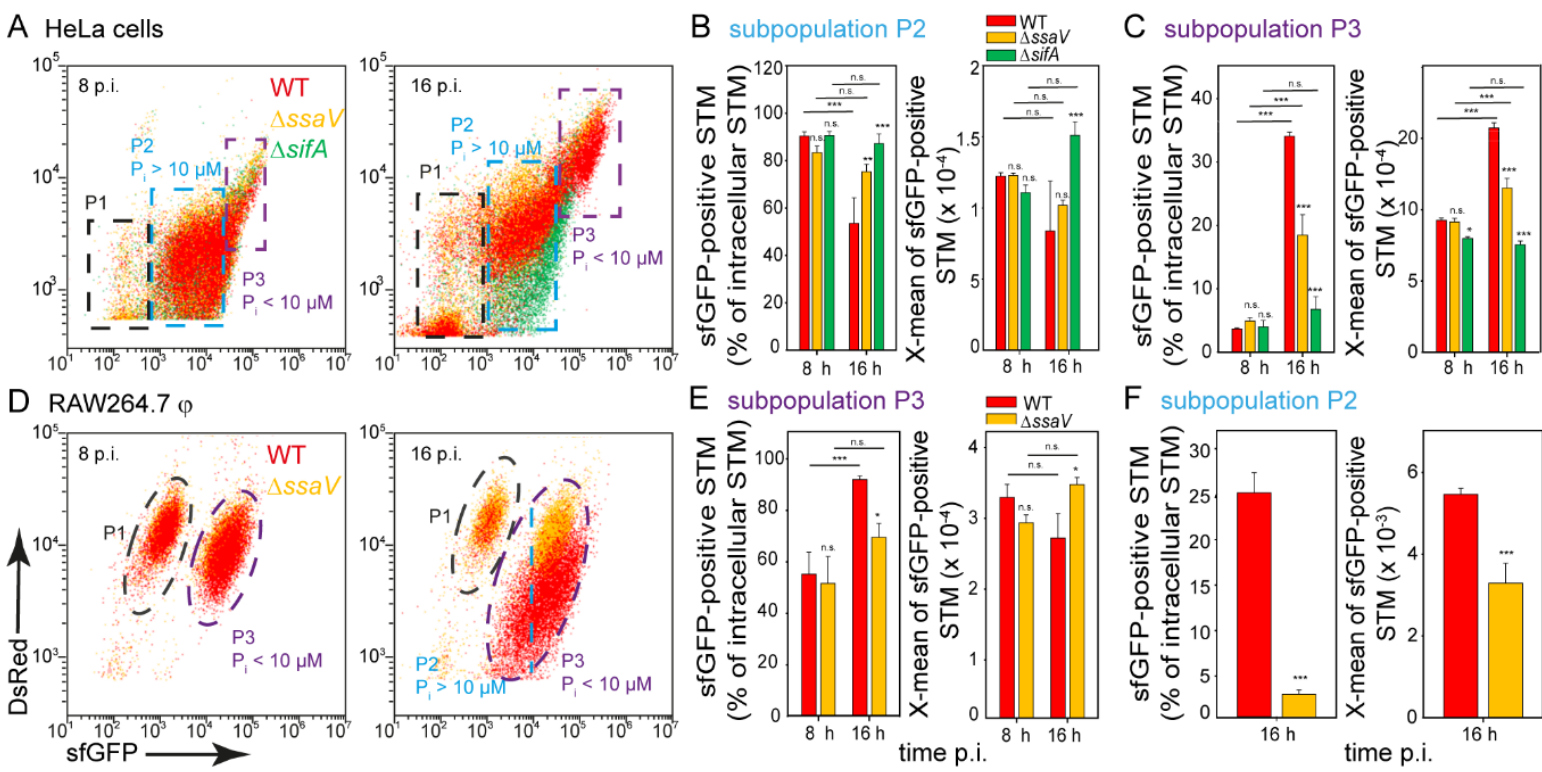

E subpopulation P3
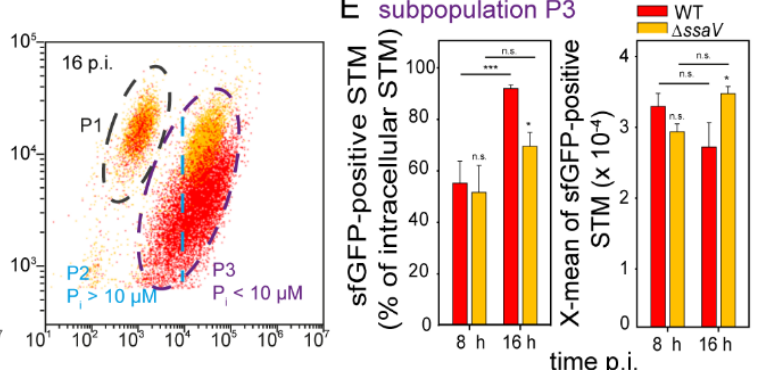

F subpopulation P2

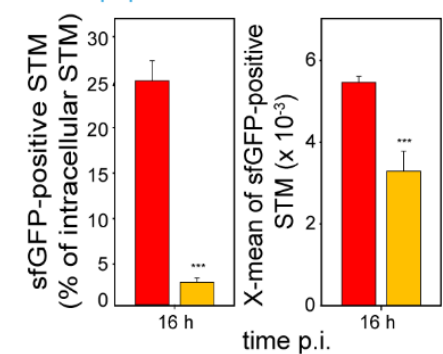

G HeLa cells
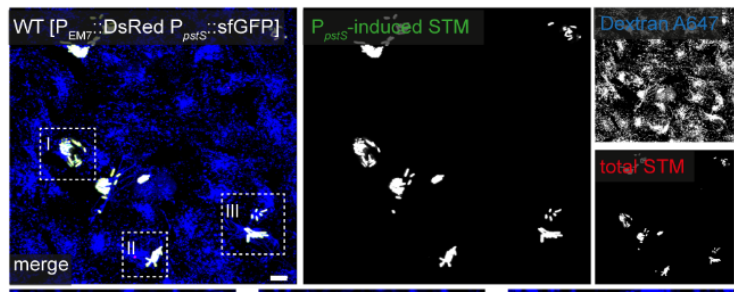

H RAW264.7 $\varphi$
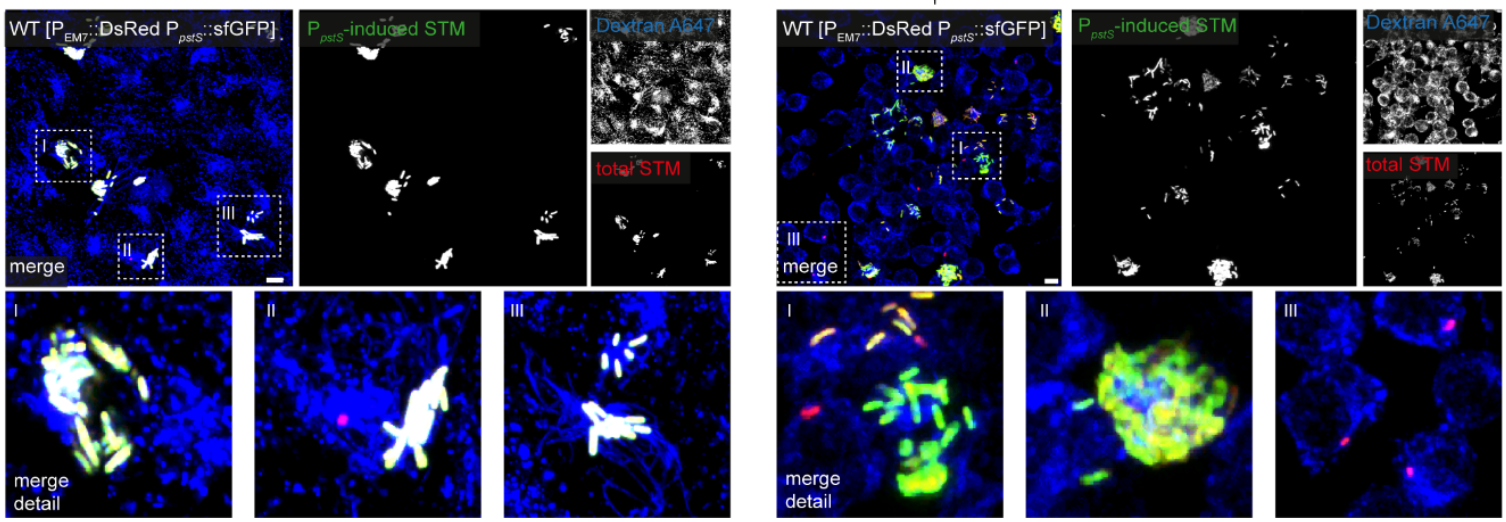

Figure 3. Determination of phosphate availability for intracellular STM in HeLa cells or

RAW264.7 macrophages. HeLa cells (A-C) or RAW264.7 macrophages (D-F) were infected

at MOI 5 with STM WT (red), $\Delta s s a V$ (orange) or $\Delta$ sifA (green) strains as indicated, each

containing the phosphate reporter p5007. A, B) Host cells were lysed $8 \mathrm{~h}$ or $16 \mathrm{~h}$ p.i., released

827 STM were fixed and subjected to FC to quantify sfGFP intensities of $\mathrm{P}_{p s t s}$-positive STM. Three

828 subpopulations of intracellular STM were distinguished based on $\mathrm{P}_{p s t}$ ::sfGFP intensity: P1,

$829 \mathrm{P}_{p s t S}$-negative; $\mathrm{P} 2, \mathrm{P}_{p s t s}$-positive at $\mathrm{P}_{\mathrm{i}}$ concentration $>10 \mu \mathrm{M}$; and $\mathrm{P} 3, \mathrm{P}_{p s t s}$-positive at $\mathrm{P}_{\mathrm{i}}$

830 concentration $<10 \mu \mathrm{M}$. Representative quantification of population size and X-means of sfGFP

831 intensities of subpopulations P2 (B, F) and P3 (C, E) for STM WT, $\Delta s s a V$ and $\Delta$ sifA strains in

832 HeLa cells (B, C), and STM WT and $\Delta s s a V$ strains in RAW264.7 macrophages (E, F) at $8 \mathrm{~h}$

833 and 16 h p.i. Mean values and standard deviations of $\mathrm{P}_{p s t s-\text {-positive bacterial subpopulations }}$

834 from triplicates of a representative experiment are shown. Statistical analyses were performed

835 by one-way ANOVA for mutant strains compared to STM WT, or between time points, and are 
bioRxiv preprint doi: https://doi.org/10.1101/2020.10.23.351551; this version posted October 23, 2020. The copyright holder for this preprint (which was not certified by peer review) is the author/funder, who has granted bioRxiv a license to display the preprint in perpetuity. It is made available under aCC-BY-NC-ND 4.0 International license.

Intracellular Salmonella phosphate availability

836 expressed as: n.s., not significant; *, p < 0.05; **, p < 0.01; ***, p < 0.001. HeLa cells (G) or 837 RAW264.7 macrophages (H) were infected with STM WT [p5007] and pulse-chased with 838 dextran-AlexaFluor 647 (blue) for labelling of the endosomal system. Live cell imaging was 839 performed $16 \mathrm{~h}$ p.i., and overview images show heterogeneous sfGFP (green) intensities of 840 STM. Representative infected cells indicate red and green fluorescence signal for STM. 841 Sections in the dashed box are shown magnified below. Scale bars, $10 \mu \mathrm{m}$.

842 
Intracellular Salmonella phosphate availability

A HeLa cells WT $\left[\mathrm{P}_{\mathrm{EMT}}:\right.$ :DsRed $\mathrm{P}_{p s t s}:$ :sfGFP]
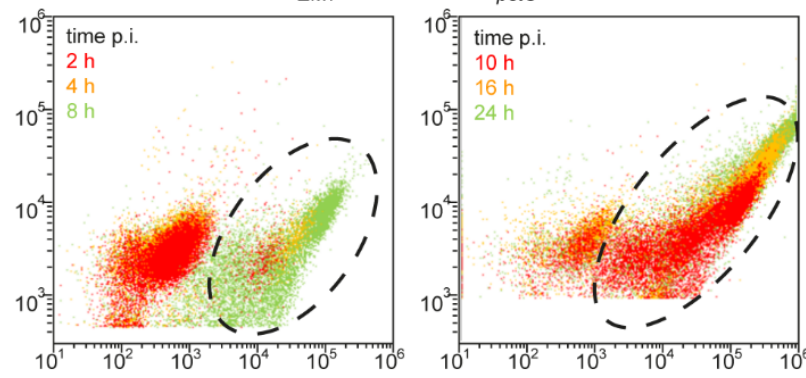

B HeLa cells $\Delta s s a V\left[\mathrm{P}_{\mathrm{EM}}:\right.$ :DsRed $\left.\mathrm{P}_{p s t s}:: \mathrm{sfGFP}\right]$
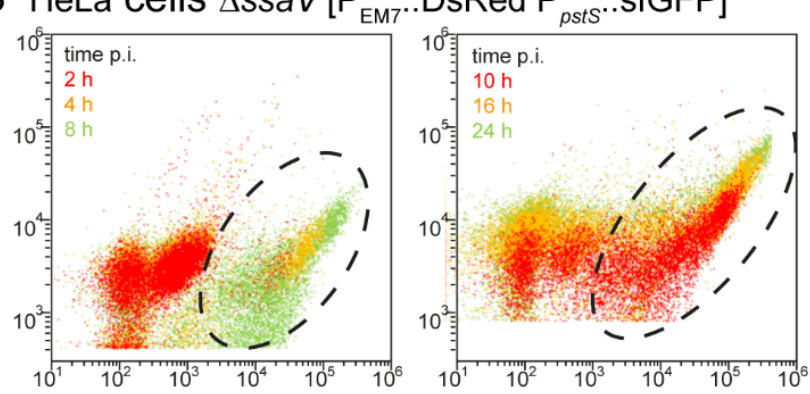

E RAW264.7 $\varphi$ WT $\left[\mathrm{P}_{\mathrm{EM}}::\right.$ :DsRed $\mathrm{P}_{\text {psts }}:$ :sfGFP]
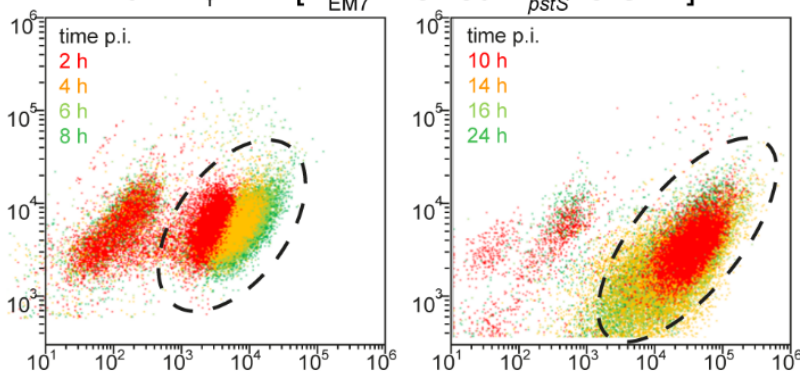

F RAW264.7 $\varphi \Delta s s a V\left[\mathrm{P}_{\mathrm{EM} 7}::\right.$ DsRed $\mathrm{P}_{p s t}::$ :sfGFP]
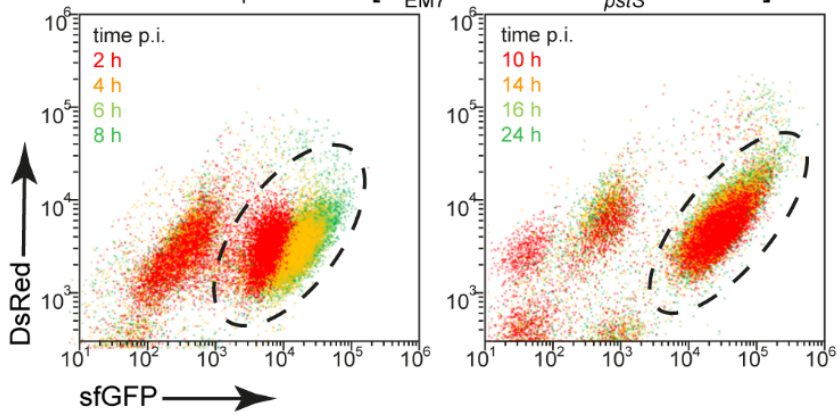
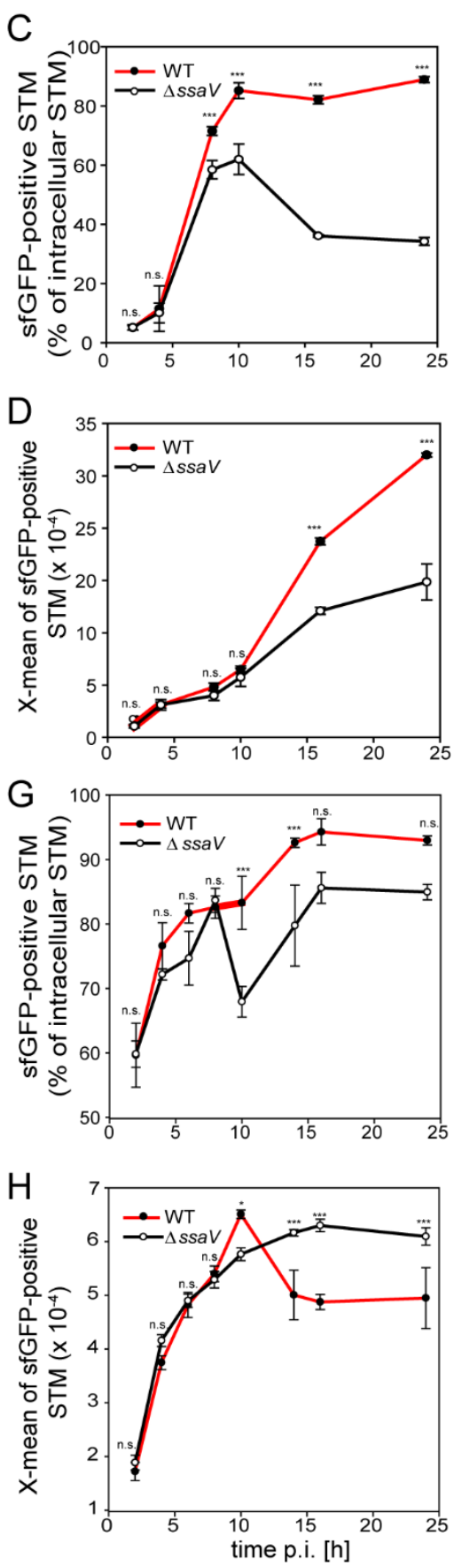

845 Figure 4. Kinetics of phosphate availability for STM in HeLa cells and RAW264.7

846 macrophages. HeLa cells (A-D) or RAW264.7 macrophages (E-H) were infected at MOI 5

847 with STM WT (A, E) or $\Delta s s a V(B, F)$ strains each harboring p5007. Host cells were lysed at

848 various time points p.i. as indicated, released bacteria were fixed and subjected to FC to quantify

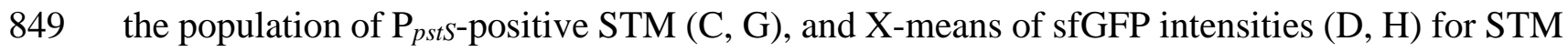

850 WT (red lines) and $\Delta s s a V$ (black lines) strains in HeLa cells or RAW264.7 macrophages. Mean 
bioRxiv preprint doi: https://doi.org/10.1101/2020.10.23.351551; this version posted October 23, 2020. The copyright holder for this preprint (which was not certified by peer review) is the author/funder, who has granted bioRxiv a license to display the preprint in perpetuity. It is made available under aCC-BY-NC-ND 4.0 International license.

Intracellular Salmonella phosphate availability

851 values and standard deviations from triplicates of a representative experiment are shown.

852 Statistical analyses are indicated as for Figure 3.

853 
Intracellular Salmonella phosphate availability

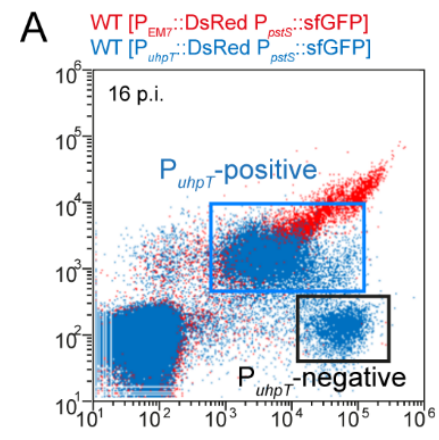

D WT $\left[\mathrm{P}_{\text {EMT }}:\right.$ :DsRed $\mathrm{P}_{\text {psS }}:$ :sfGFP]

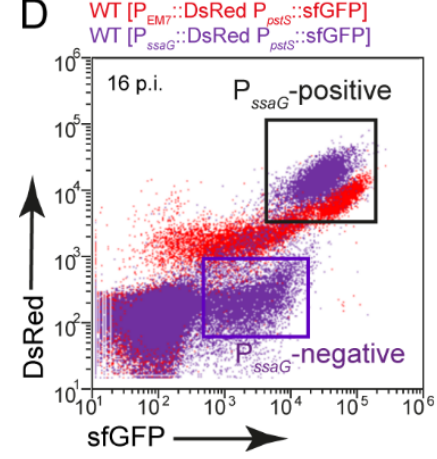

$\mathrm{B}$

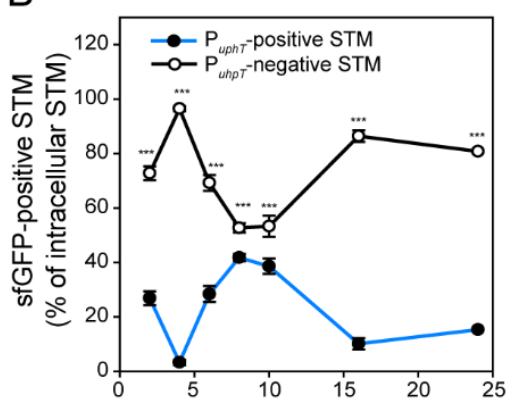

$\mathrm{E}$

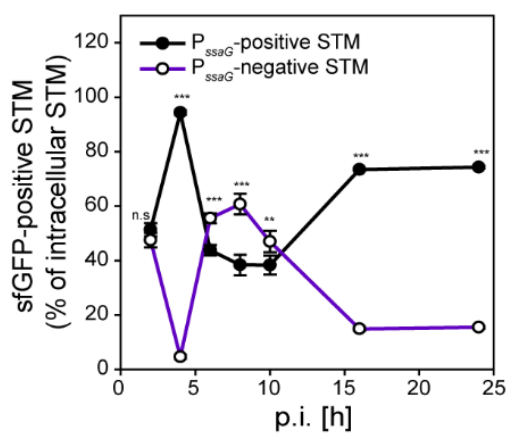

C

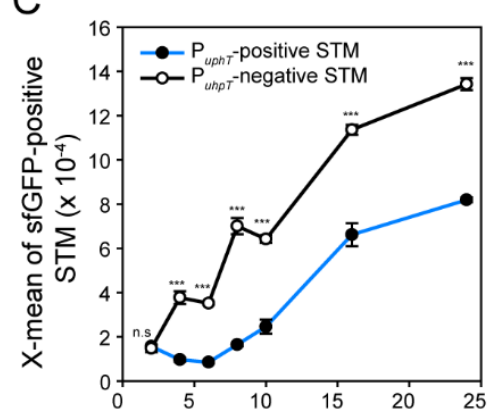

$\mathrm{F}$

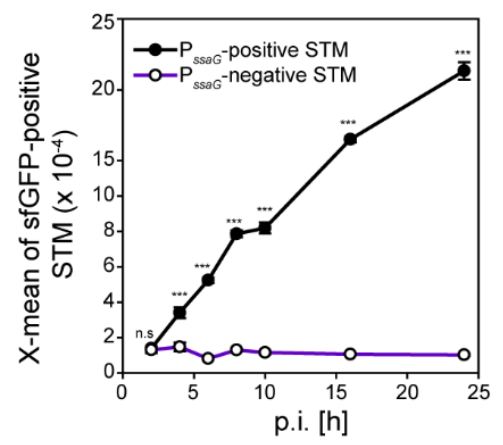

Figure 5. Higher phosphate availability for STM in host cell cytosol. HeLa cells were

857 infected at MOI 5 with STM WT harboring p5193 with DsRed under control of $\mathrm{P}_{u h p T}$ and $858 \mathrm{P}_{p s t}:$ ::sfGFP (blue), or p5457 for expression of DsRed under control of $\mathrm{P}_{s s a G}$, and $\mathrm{P}_{p s t S:: s f G F P}$ 859 (violet). For comparison and gating of populations, HeLa cells were infected with STM WT 860 harboring p5007 for constitutive expression of DsRed and $\mathrm{P}_{p s t}:$ :sfGFP (red). Host cells were 861 lysed at various points in time p.i. as indicated, released STM were fixed and subjected to FC 862 for quantification of $\mathrm{P}_{p s t s}$-positive bacteria. Induction of $\mathrm{P}_{u h p T}$ or $\mathrm{P}_{s s a G}$ was determined. Data for 863 STM WT [p5007] and WT [p5193] (A), or STM WT [p5007] and WT [p5457] (D) of a 864 representative experiment are shown. The sizes (B, E) and sfGFP intensities (C, F) of the

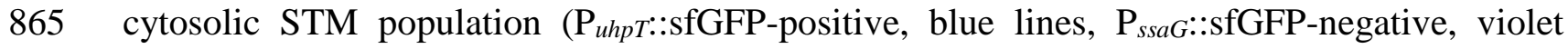

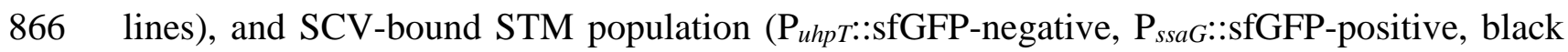
867 lines) were quantified and mean values and standard deviations for represent data from 868 triplicates are shown. Statistical analyses are indicated as for Figure 3. 
bioRxiv preprint doi: https://doi.org/10.1101/2020.10.23.351551; this version posted October 23, 2020. The copyright holder for this preprint (which was not certified by peer review) is the author/funder, who has granted bioRxiv a license to display the preprint in perpetuity. It is made available under aCC-BY-NC-ND 4.0 International license.

Intracellular Salmonella phosphate availability

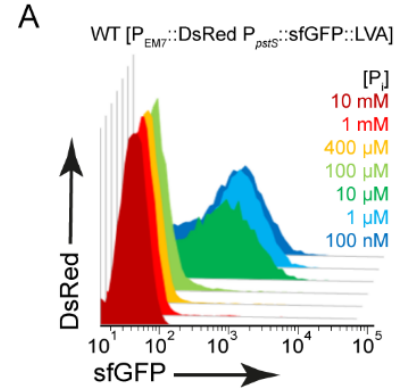

$\mathrm{E}$
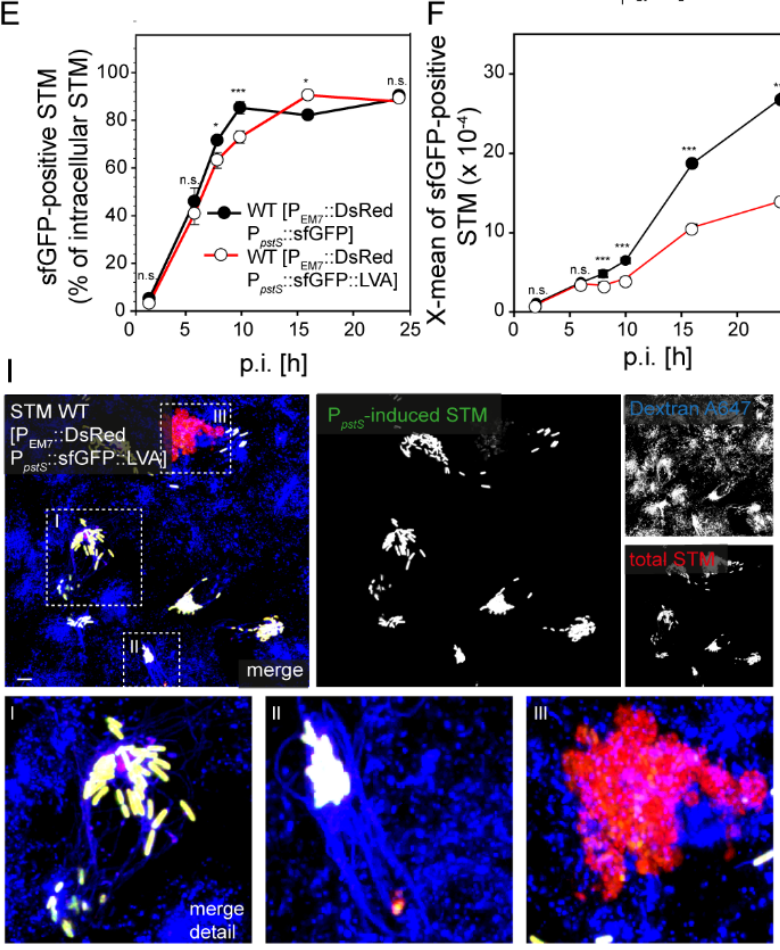
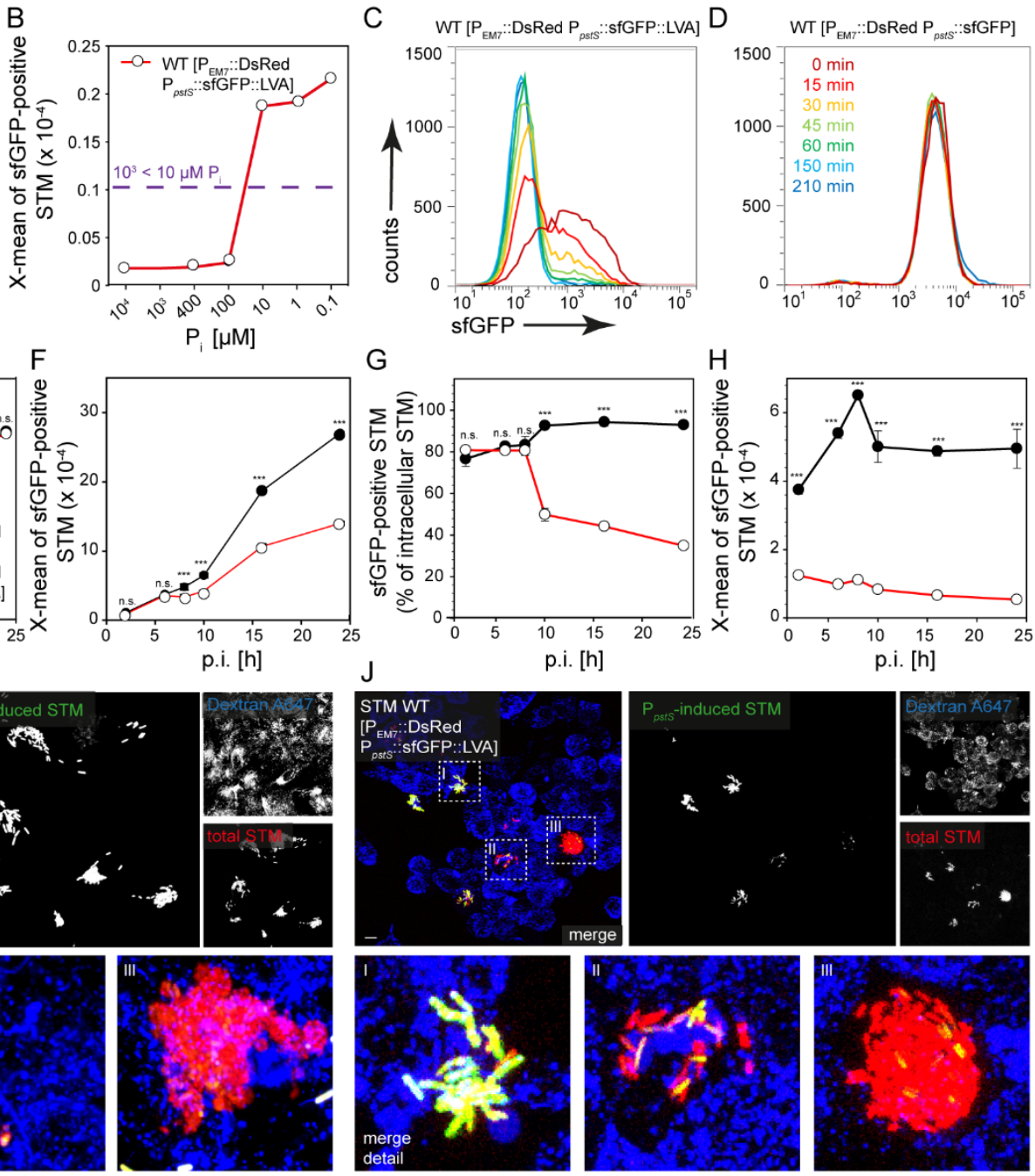

Figure 6. Phosphate limitation for STM in IFN- $\gamma$-activated RAW264.7 macrophages and monocyte-derived human macrophages. A, B) RAW264.7 macrophages were cultured for $24 \mathrm{~h}$ in medium without (blue) or with (red) $5 \mathrm{ng} \mathrm{x} \mathrm{ml} \mathrm{IFN}^{-1} \gamma$, and subsequently infected with STM WT [p5007] at MOI 5. C, D) Human peripheral blood macrophages (red, orange) or RAW264.7 macrophages (light green, dark green) were infected with STM WT [p5007] at MOI 25. Host cells were lysed as indicated at 8 h p.i. or 16 h p.i., released STM were fixed and subjected to FC to quantify $\mathrm{P}_{p s t S}$-positive STM and X-means of sfGFP intensities for $\mathrm{P}_{p s t S^{-}}$ positive STM (B, D). Data of representative experiments are shown, (A) for STM WT [p5007] in resting RAW264.7 (red) and activated RAW264.7 (blue), (C) for STM WT [p5007] in RAW264.7 (light green, dark green). or human macrophages (red, orange) Mean values and standard deviations from triplicates of a representative experiment are shown. Statistical analyses are indicated as for Figure 3. 
Intracellular Salmonella phosphate availability

A

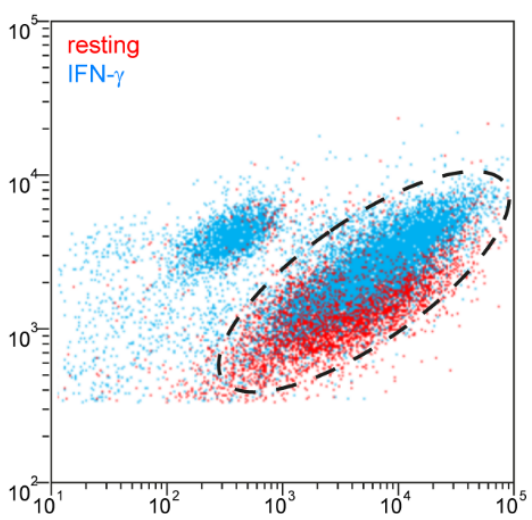

C

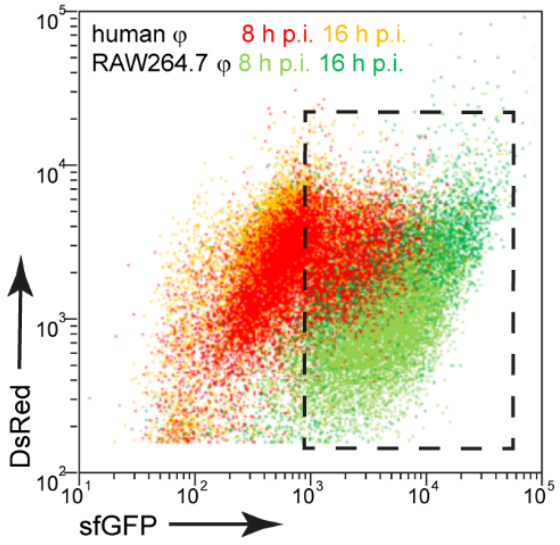

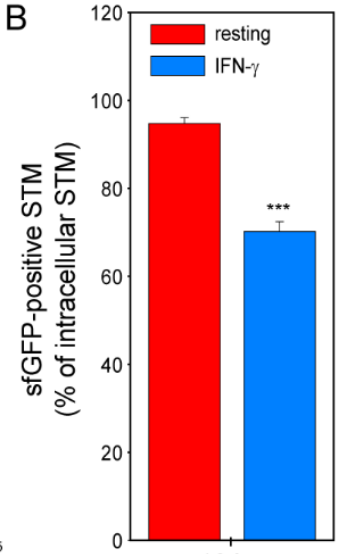

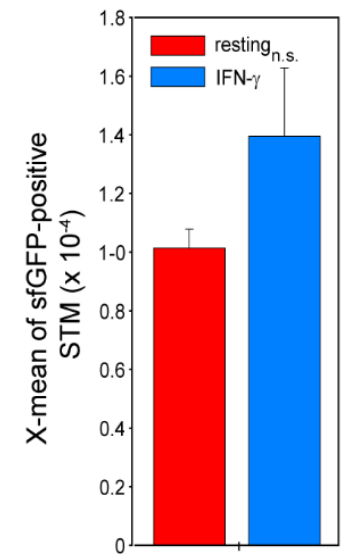

$16 \mathrm{~h}$
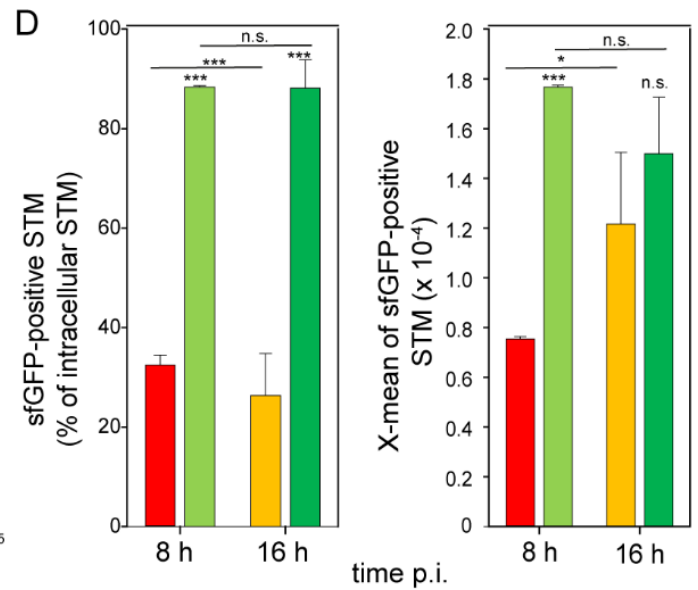

Figure 7. Analyses of dynamics in phosphate availability using a reporter with

destabilized sfGFP. STM harbored p5440 for constitutive expression of DsRed, and

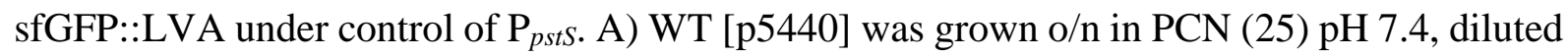
1:100 in PCN (1), $\mathrm{pH}$ 5.8, and subcultured to $\mathrm{OD}_{600}$ 0.5-0.7. This culture was used to inoculate PCN media with various concentrations of $P_{i}$ as indicated, and culture was continued for $1 \mathrm{~h}$. B) The sfGFP intensities of $\mathrm{P}_{p s t s}$-induced STM was determined by FC. Phosphate concentrations lower than $10 \mu \mathrm{M} \mathrm{P}_{\mathrm{i}}$ corresponded to sfGFP intensities higher than $10^{3} \mathrm{RFI}$. sfGFP intensities of $\mathrm{P}_{\text {psts-positive bacteria of a representative experiment are shown. } \mathrm{C}, \mathrm{D}) \mathrm{The}}$ stability of sfGFP and sfGFP::LVA was determined. WT [p5007] or WT [p5440] were diluted 1:31 in PCN (0.01), pH 5.8 and subcultured for 2 h. Chloramphenicol was added to $200 \mathrm{ng} \mathrm{x}$ $\mathrm{ml}^{-1}$ final concentration to inhibit bacterial protein synthesis. The culture was further incubated, and sfGFP intensities were determined at various culture times as indicated. HeLa cells (E, F) or RAW264.7 macrophages (G, H) were infected with STM WT [p5007] or WT [p5440] at MOI 5. Host cells were lysed at various time points p.i., released STM were fixed and subjected

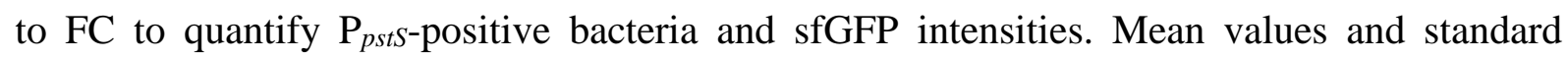


Intracellular Salmonella phosphate availability

902 deviations of triplicates of a representative experiment are shown. Statistical analyses are 903 indicated as for Figure 3. HeLa cells (I) or RAW264.7 macrophages (J) were infected with 904 STM WT [p5440] and pulse-chased with dextran-AlexaFluor 647 for labelling of the 905 endosomal system. Live cell imaging was performed 16 h p.i. Representative infected cells 906 showed red and green fluorescence signals for STM. Sections in the dashed box are shown 907 magnified below. Scale bars, $10 \mu \mathrm{m}$. 
Intracellular Salmonella phosphate availability
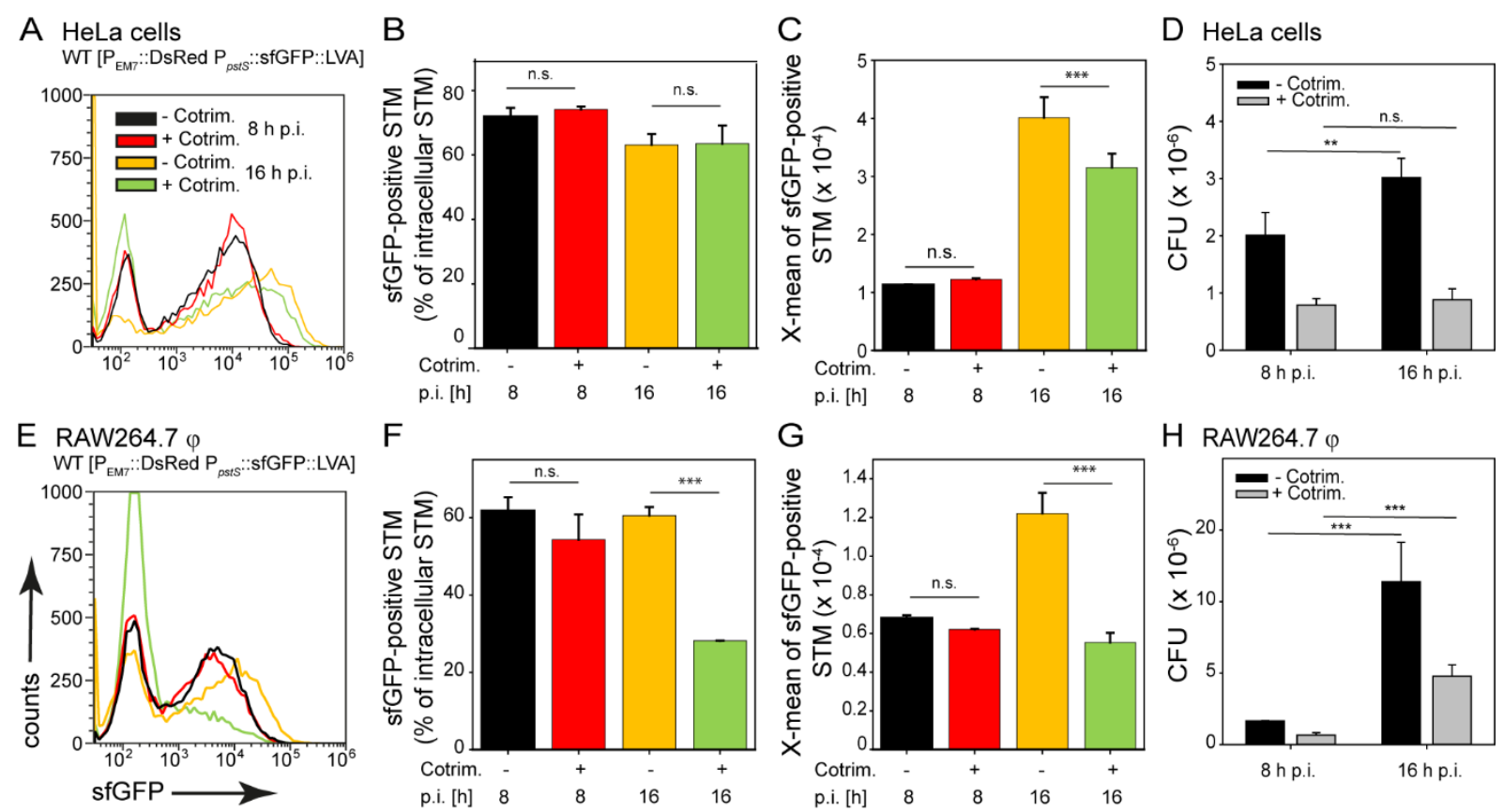

Figure 8. Inhibition of bacterial proliferation ablates intracellular phosphate limitation.

911 HeLa cells (A-D) or RAW264.7 macrophages (E-H) were infected with STM WT [p5440] at

912 MOI 5. If indicated, Cotrimoxazole was added at $1 \mathrm{~h}$ p.i. to $100 \mathrm{ng} \mathrm{x} \mathrm{ml}^{-1}$ final concentration to

913 infected cells in order to arrest STM intracellular proliferation. Host cells were lysed 8 h p.i.

914 (black, red) or 16 h p.i. (orange, green), released STM were fixed and subjected to FC for

915 quantification of $\mathrm{P}_{p s t s}$-positive STM (B, F), and X-means for sfGFP intensities of $\mathrm{P}_{p s t S}$-positive

916 STM (C, G). Representative data are given for STM WT in nontreated or Cotrimoxazole-treated

917 HeLa cells (A) or RAW264.7 macrophages (E). Mean values and standard deviations of

918 triplicates of a representative experiment are shown. D, H) Host cells were lysed $8 \mathrm{~h}$ or $16 \mathrm{~h}$

919 p.i., released STM were plated onto agar plate to determine CFU of intracellular STM in

920 nontreated (black bars) and in Cotrimoxazole-treated (grey bars) HeLa cells (D), or RAW264.7

921 macrophages $(\mathrm{H})$. Statistical analyses are indicated as for Figure 3. 
Intracellular Salmonella phosphate availability
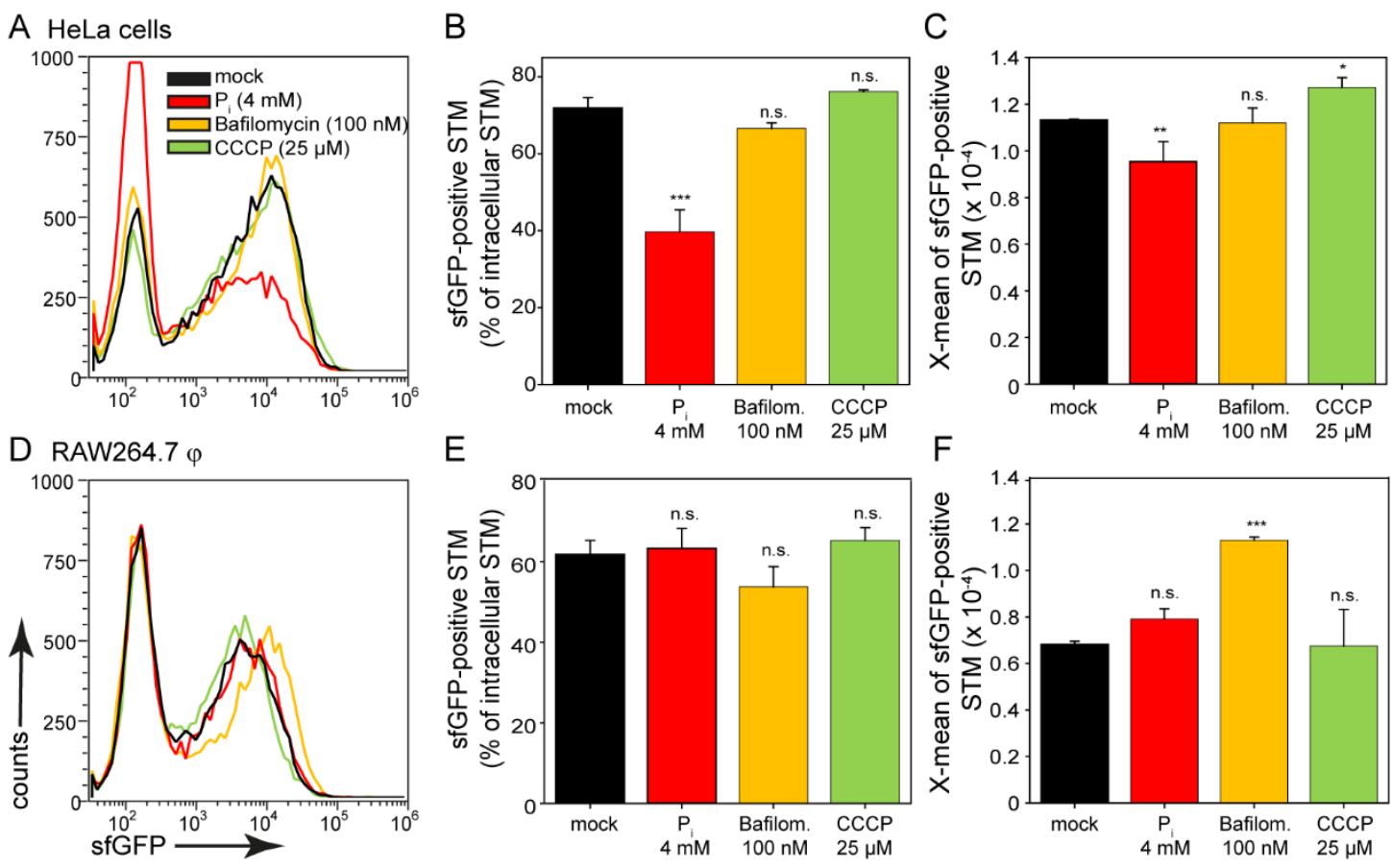

Figure 9. Manipulation of SCV pH and phosphate availability for STM in host cells. HeLa cells (A-C) or RAW264.7 macrophages (D-F) were infected by STM WT [p5440] at MOI 5.

927 Infected cell were left untreated (mock, black), or experimentally manipulated. To alter $\mathrm{P}_{\mathrm{i}}$ 928 availability, $4 \mathrm{mM} \mathrm{P}$ i was added to cells $24 \mathrm{~h}$ prior infection by STM and maintained during 929 infection (red). vATPase inhibitor Bafilomycin (orange) or ionophor CCCP (green) were added 930 at $25 \mu \mathrm{M}$ or $100 \mathrm{nM}$ final concentration, respectively, to infected cells at $1 \mathrm{~h}$ p.i., and maintained 931 throughout the infection period. Infected host cells were lysed $8 \mathrm{~h}$ p.i., released STM were fixed 932 and subjected to FC for quantification of $\mathrm{P}_{p s t s}$-positive STM (B, E), and the X-means for sfGFP

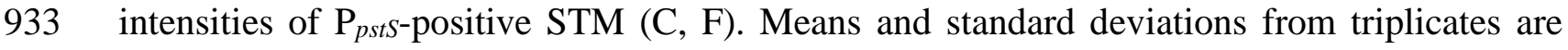
934 shown. Representative data for STM WT in nontreated and treated HeLa cells (A), or 935 RAW264.7 macrophages (D). Statistical analyses are indicated as for Figure 3. 
Intracellular Salmonella phosphate availability

A

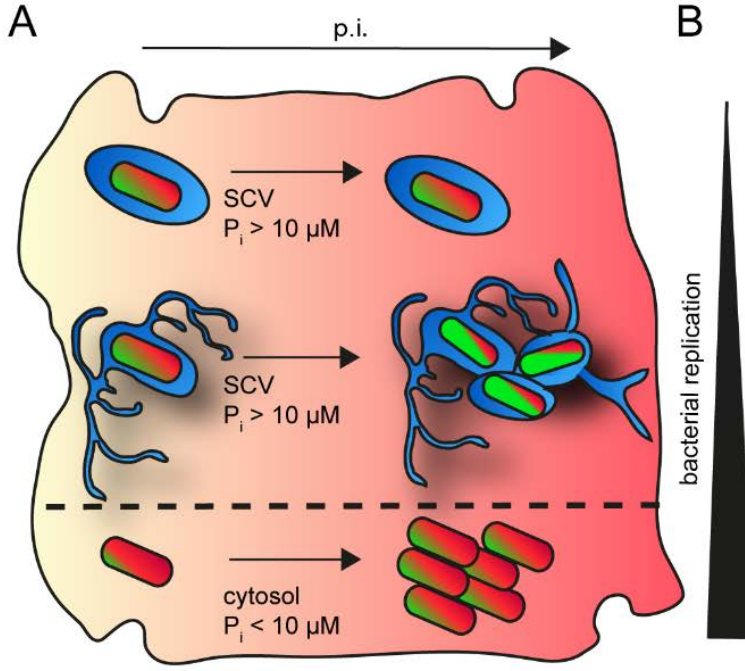

$P$ concentration

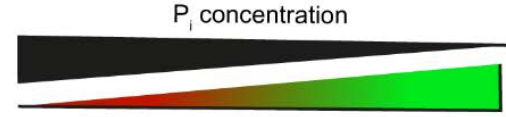

$\mathrm{P}_{p s t S}$ induction

$\mathrm{C}+\mathrm{P}_{\mathrm{i}}(4 \mathrm{mM})$

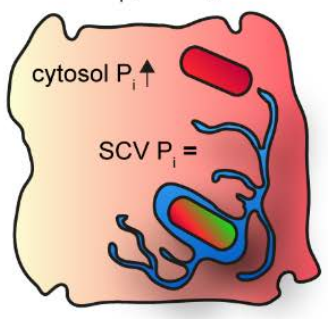

$\mathrm{D}+\operatorname{CCCP}(25 \mu \mathrm{M})$

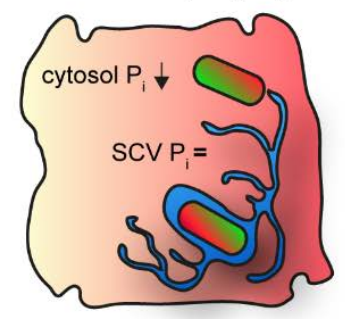

$\mathrm{P}_{\mathrm{i}}$ transport $=\mathrm{P}_{\mathrm{i}}$ consumption

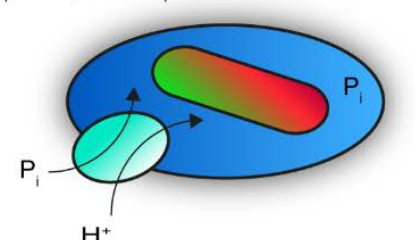

$\mathrm{H}^{+}$

enlarged SCV/SIF = increases $\mathrm{P}$ transport more replication and $\mathrm{P}_{\mathrm{i}}$ consumption

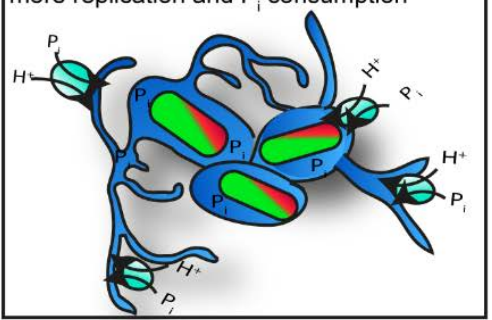

$\mathrm{E}+$ Bafilomycin (100 nM)

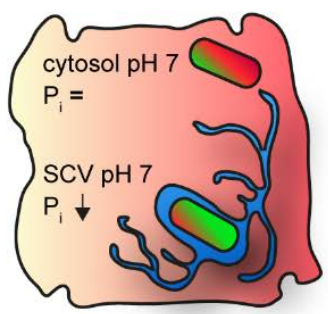

Figure 10. Model of factors that influence $\mathbf{P}_{p s t}$ induction of STM in host cells. A) The $P_{p s t S}$

940 induction depends on the vacuolar or cytosolic presence of STM, and the level of intracellular

941 replication. B) Replication-arrested STM demand less phosphate. An enlargement of the SCV-

942 SIF continuum leads to an increased phosphate import, but also to increased replication and

943 phosphate consumption. C) External addition of phosphate led to increased intracellular 944 phosphate concentration in host cell cytosol, but not within SCV. D) Addition of CCCP led to 945 decreased intracellular phosphate concentration in host cells cytosol, but not within the SCV.

946 E) Bafilomycin changed the $\mathrm{pH}$ within the SCV and led to lower phosphate availability. 

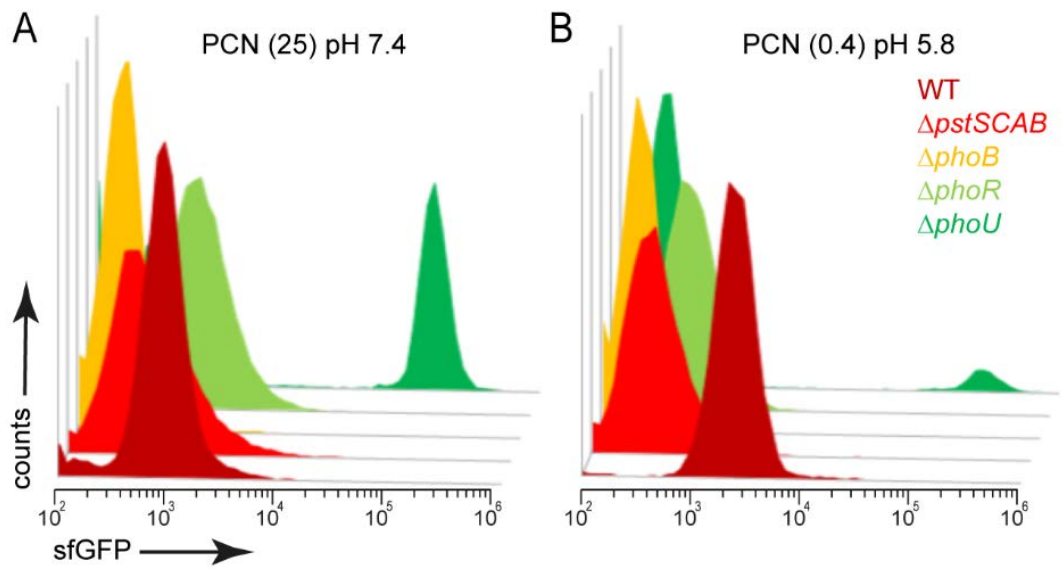

951 Figure S 1: The phosphate reporter $\mathbf{P}_{p s t s}$ : :sfGFP is responsive to defects in PstSCAB,

952 PhoB, PhoR, or PhoU. STM WT, $\triangle p s t S C A B, \triangle p h o B, \triangle p h o R$, or $\triangle p h o U$ strains, all harboring

953 p5007 were grown in PCN minimal medium (A) at pH 7.4 containing $25 \mathrm{mM} \mathrm{Pi}$ (PCN (25)

$954 \mathrm{pH7.4)}$ ), or (B) at pH 5.8 containing $0.4 \mathrm{mM} \mathrm{P}$ ( $\mathrm{PCN}(0.4) \mathrm{pH}$ 5.8). Samples were collected

955 after $3.5 \mathrm{~h}$ of culture and sfGFP intensity of $\mathrm{P}_{p s t s-\text { induced bacteria was determined by flow }}$ 956 cytometry (FC). 
Intracellular Salmonella phosphate availability

A WT $\left[P_{\text {EM7 }}::\right.$ DsRed $P_{\text {apeE: }}::$ sfGFP]
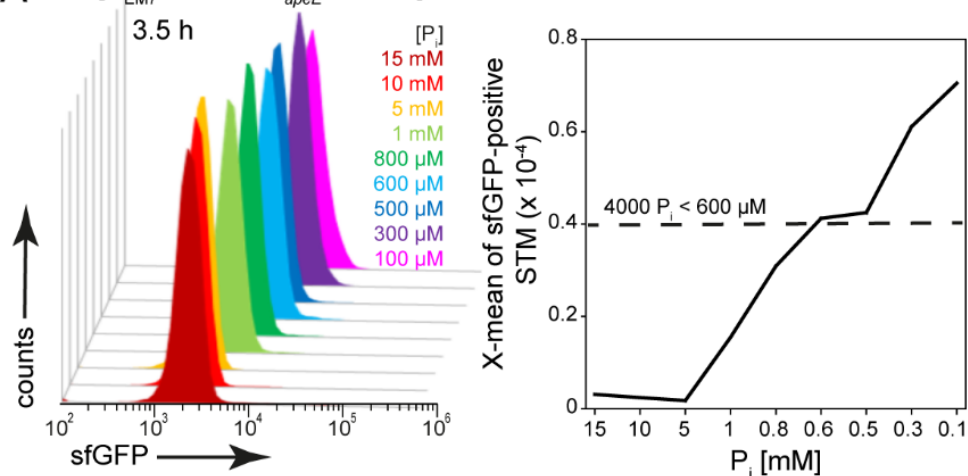

B
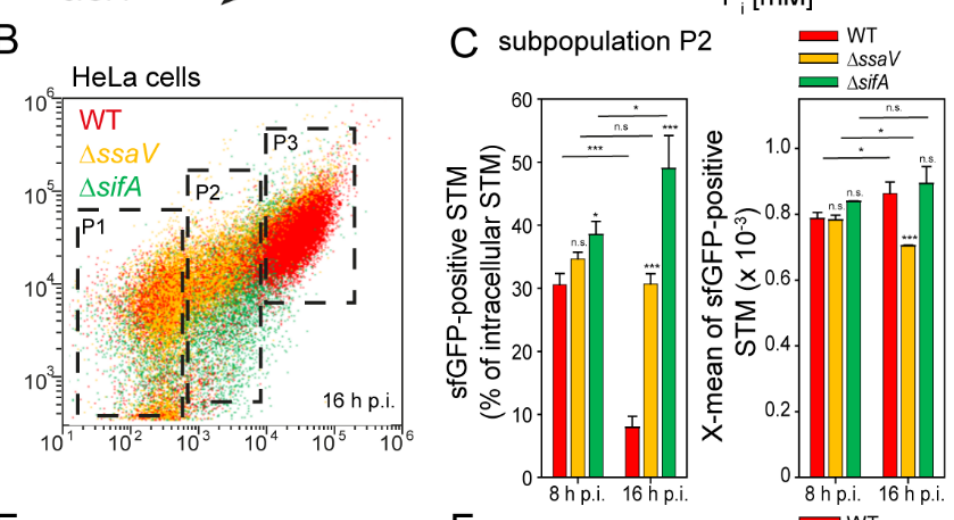

D subpopulation P3
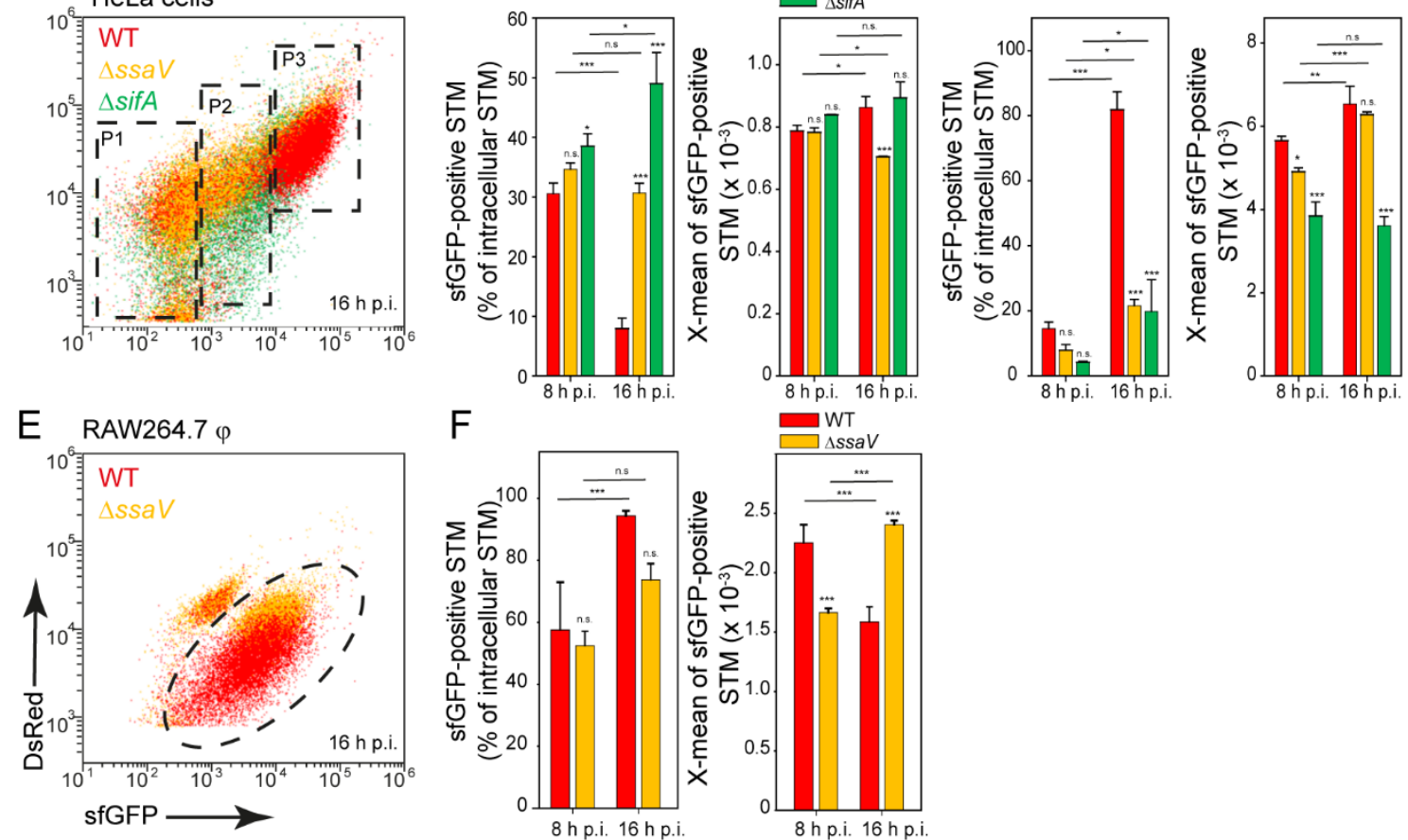

Figure S 2: Performance of an alternative dual fluorescence phosphate reporter based on

PapeE::sfGFP. STM strains harbored p5081 for constitutive expression of DsRed and sfGFP

under control of $\mathrm{P}_{a p e E}$. A) Induction of $\mathrm{P}_{\text {apeE }}:$ :sfGFP in vitro during growth in presence of various phosphate concentrations [ $\mathrm{P}_{\mathrm{i}}$ ]. STM WT [p5007] was grown o/n in PCN (25), pH 7.4 and then diluted 1:31 in PCN, $\mathrm{pH} 7.4$ with various concentrations of $\mathrm{P}_{\mathrm{i}}$ as indicated. Samples were collected after $3.5 \mathrm{~h}$ of subculture and sfGFP intensities of $\mathrm{P}_{a p e E}$-induced bacteria was determined by FC. HeLa cells (B-D) or RAW264.7 macrophages (E, F) were infected at MOI of 5 with STM WT (red), $\Delta s s a V$ (orange) or $\Delta s i f A$ (green) strains as indicated, each containing the phosphate reporter p5081. The host cells were lysed $8 \mathrm{~h}$ or $16 \mathrm{~h}$ p.i., and released STM were fixed. Subsequently, the bacteria were subjected to FC to quantify the size of the induced intracellular population and X-means of sfGFP intensity of the $\mathrm{P}_{a p e E}$-induced bacteria. The 
bioRxiv preprint doi: https://doi.org/10.1101/2020 10.23.351551; this version posted October 23, 2020. The copyright holder for this preprint (which was not certified by peer review) is the author/funder, who has granted bioRxiv a license to display the preprint in perpetuity. It is made available under aCC-BY-NC-ND 4.0 International license.

Intracellular Salmonella phosphate availability

971 bacterial population was divided into 3 subpopulations based on $\mathrm{P}_{\text {apeE }}$ intensity. Representative

972 data for STM WT, $\Delta s s a V$ and $\Delta s i f A$ strains at $8 \mathrm{~h}$ and $16 \mathrm{~h}$ p.i. in HeLa cells (C, D), and for

973 STM WT and $\Delta s s a V$ strains at $8 \mathrm{~h}$ and $16 \mathrm{~h}$ p.i. in RAW264.7 macrophages (F). Mean values

974 and standard deviations of the $\mathrm{P}_{a p e E}$-positive bacteria populations from triplicates of a

975 representative experiment are shown. Statistical analyses are indicated as for Figure 3.

976 
Intracellular Salmonella phosphate availability
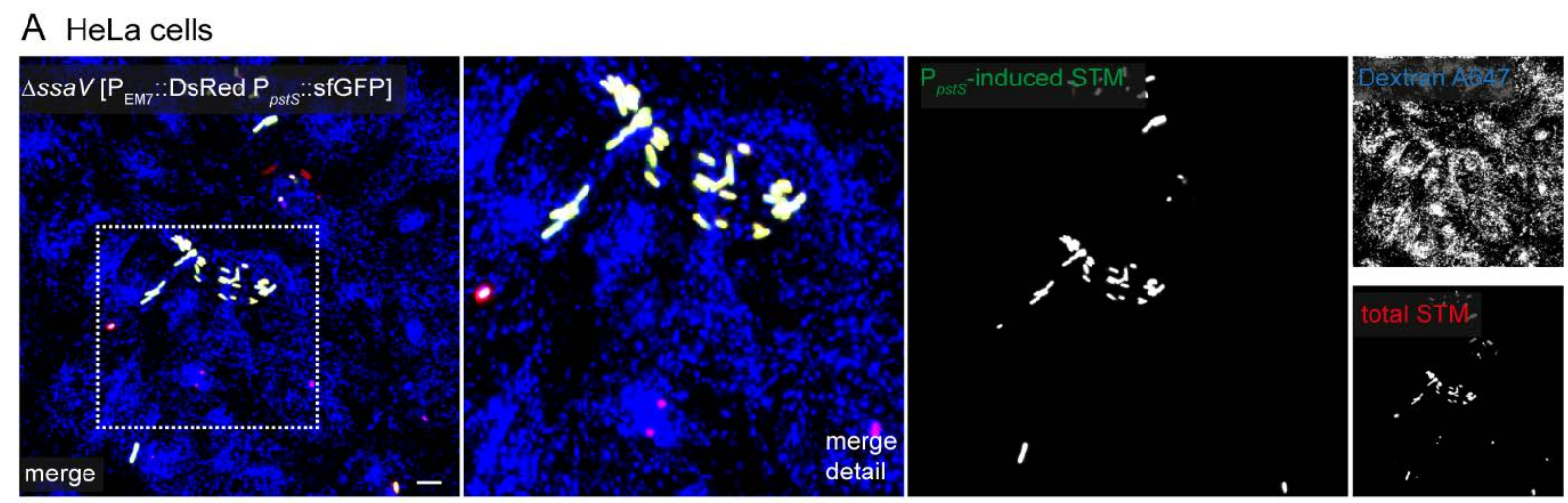

B RAW264.7 $\varphi$
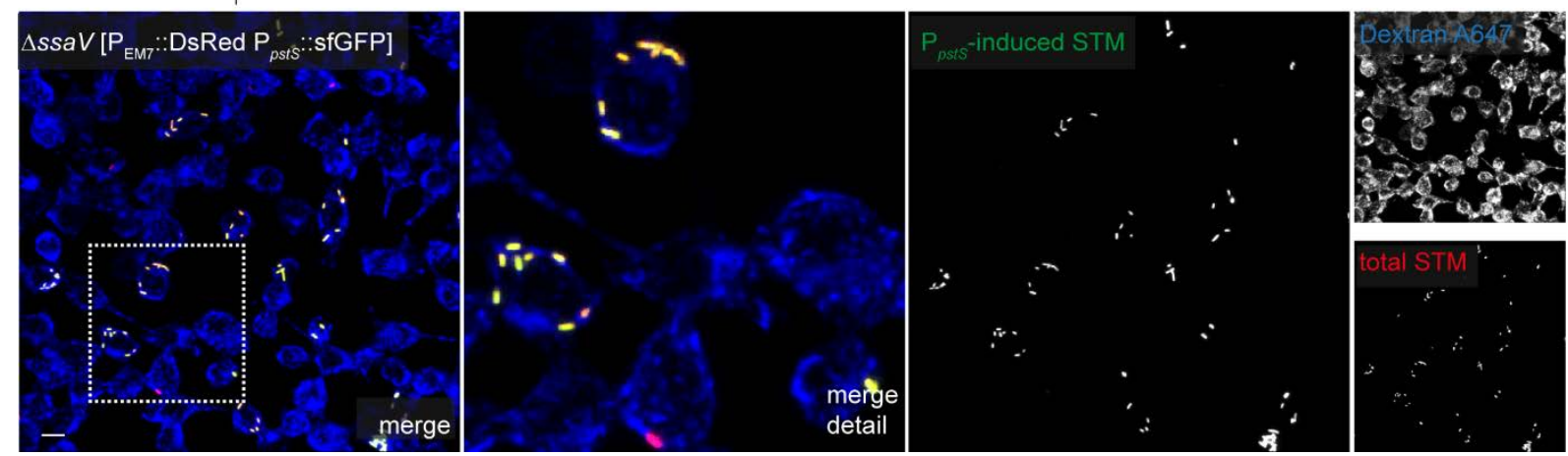

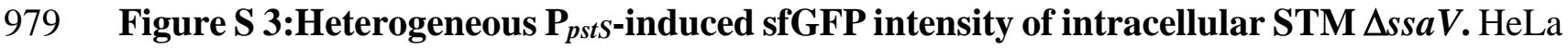

980 cells (A), or RAW264.7 macrophages (B) were infected by STM $\Delta s s a V$ [p5007] and pulse-

981 chased with dextran-AlexaFluor 647 for labelling of the endosomal system. Live cell imaging

982 was performed $16 \mathrm{~h}$ p.i. Representative infected cells indicate red and green fluorescence signal 983 for STM. Scale bars, $10 \mu \mathrm{m}$. 
Intracellular Salmonella phosphate availability
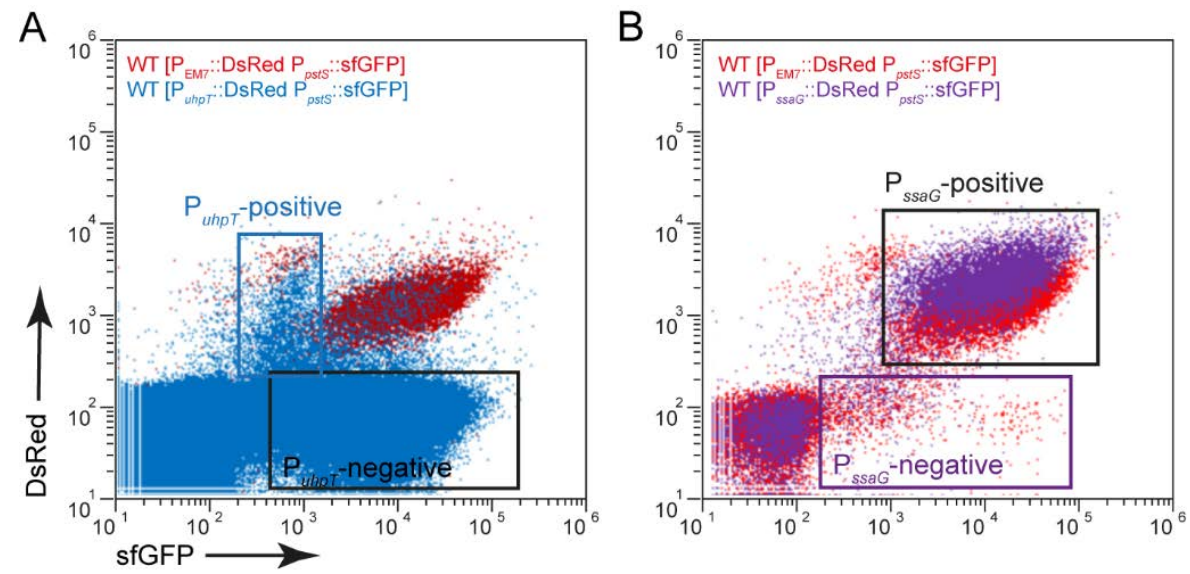

987 Figure S 4: Cytosolic bacteria are rarely found in RAW264.7 macrophages. RAW264.7

988 macrophages were infected with STM WT [p5193] (blue) or STM WT [p5457] (violet) at a

989 MOI of 5. For comparison and gating of populations, cells were infected with STM WT [p5007]

990 (red). At 16 h p.i., host cells were lysed, released bacteria fixed and subjected to FC for

991 quantification of intracellular STM positive for $\mathrm{P}_{u h p T}, \mathrm{P}_{s s a G}$, and/or $\mathrm{P}_{p s t s}$. Representative data are

992 shown for (A) STM WT [p5193], and (B) STM WT [p5457].

993 
Intracellular Salmonella phosphate availability
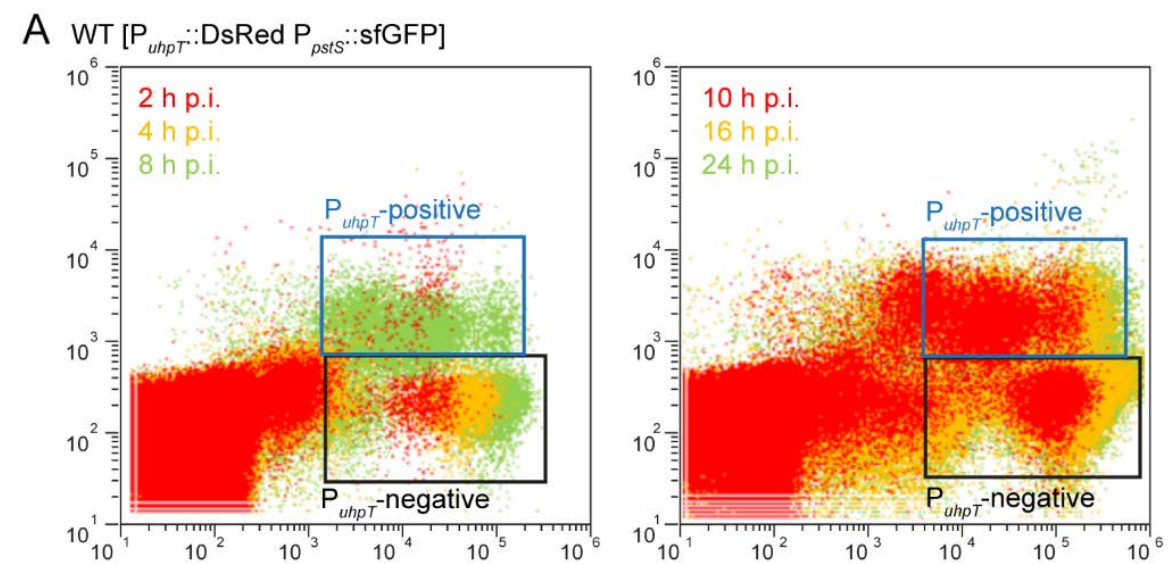

B WT $\left[\mathrm{P}_{\text {ssaG }}::\right.$ DsRed $\mathrm{P}_{\rho s t}::$ :SfGFP]
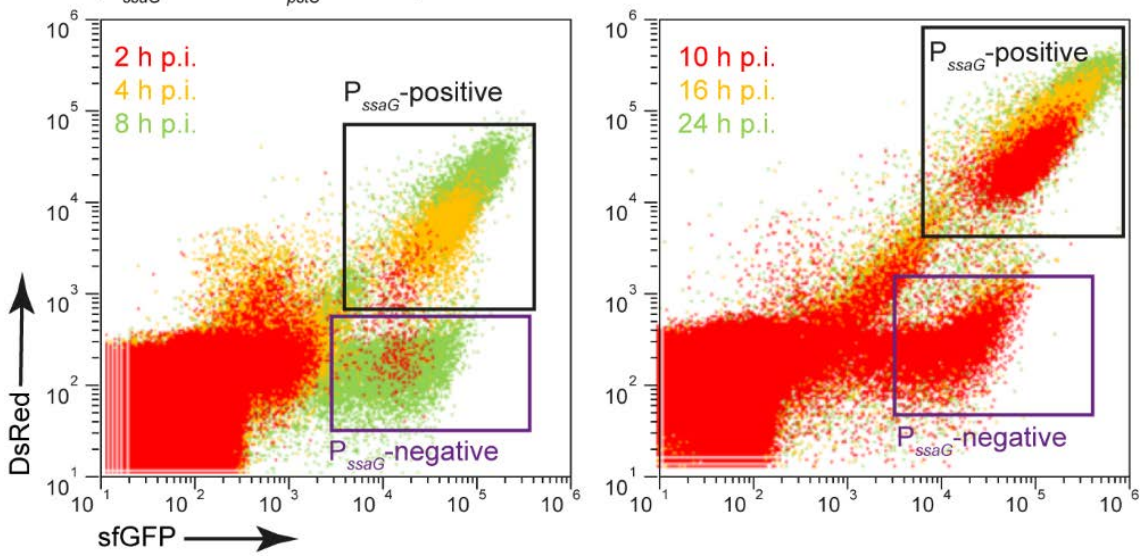

Figure S 5: Cytosolic STM encounter higher phosphate concentration than SCV-bound

997 bacteria. HeLa cells were infected with (A) STM WT [p5193], or (B) STM WT [p5457] at a

998 MOI of 5. At various time points p.i., host cells were lysed, released bacteria fixed and subjected

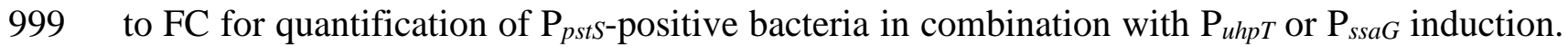

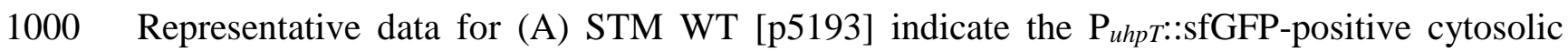
1001 population, and (B) STM WT [p5457] indicate the $\mathrm{P}_{\text {ssaG }}:$ :sfGFP-positive SCV-bound 1002 population. 
Intracellular Salmonella phosphate availability

A WT $\left[P_{E M T}:: R F P P_{s s a G}::\right.$ SfGFP]

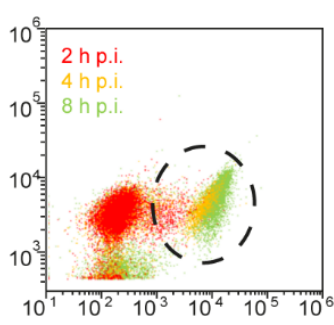

D WT [P $P_{\text {EMT }}:$ RFP $P_{\text {ssa }:}:$ :sfGFP]

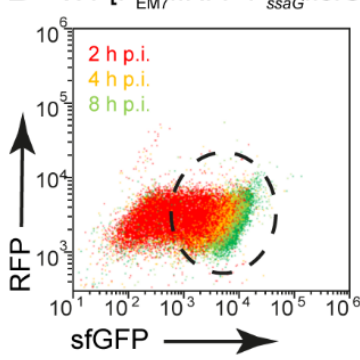

B

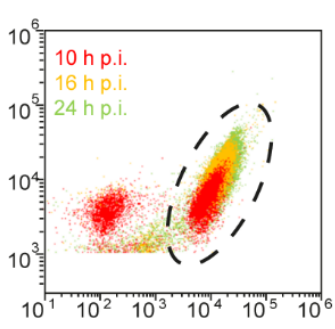

$E$

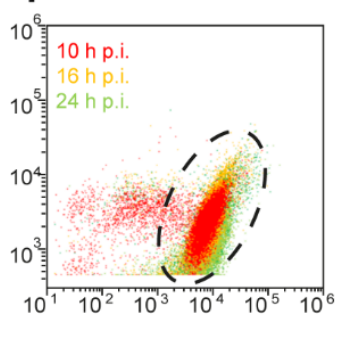

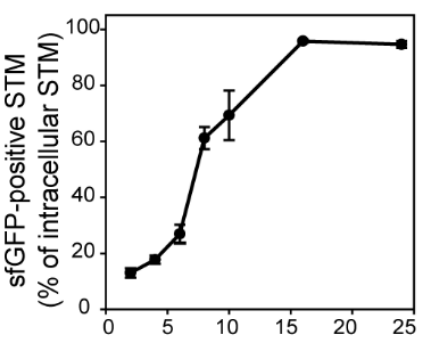

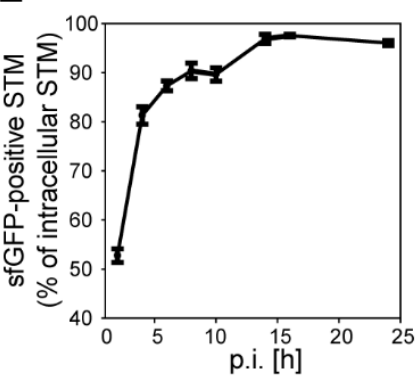

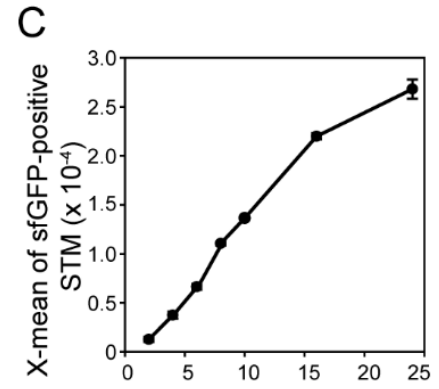

$\mathrm{F}$

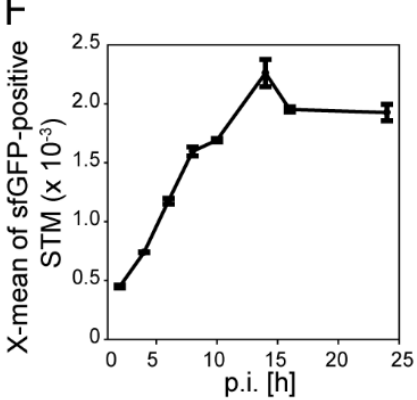

Figure S 6: SPI2-T3SS activity increases in HeLa cells and RAW macrophages. STM WT harboring p3776 for constitutive expression of RFP and sfGFP under control of $\mathrm{P}_{\text {ssa }}$ was used to infect HeLa cells (A-C) or RAW264.7 macrophages (D-F) at MOI of 5. At various time points p.i., host cells were lysed, released STM were fixed and subjected to FC for quantification of $\mathrm{P}_{s s a G}$-positive bacteria and sfGFP intensity. Means and standard deviations for the size of the $\mathrm{P}_{\text {ssaG }}$ :sfGFP-induced population (B, E) and X-means of sfGFP-fluorescence (C, F) from triplicates are shown for various time points p.i. Representative data for STM WT in HeLa cells (A) or in RAW264.7 macrophages (D). 
Intracellular Salmonella phosphate availability

A WT $\left[P_{\text {EM }}::\right.$ DsRed $P_{p s t S}::$ sfGFP::LVA]
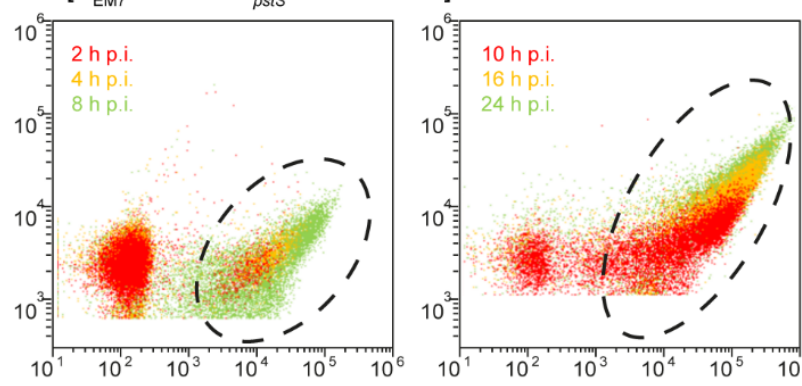

$\mathrm{B}$
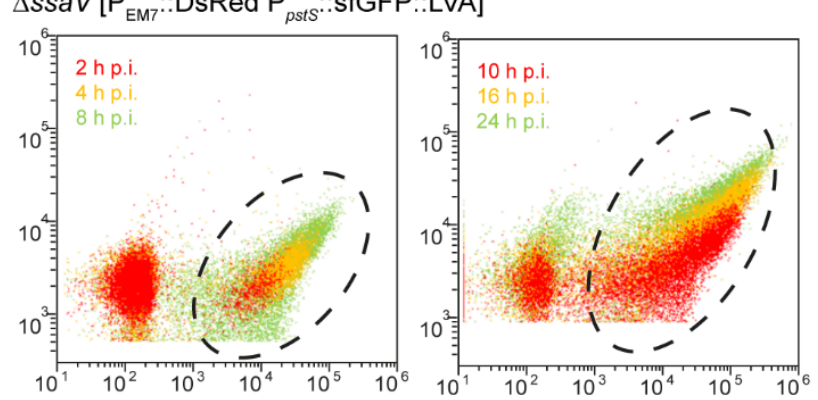

E WT $\left[P_{E M 7}::\right.$ DsRed $P_{p s t s}::$ sfGFP::LVA]
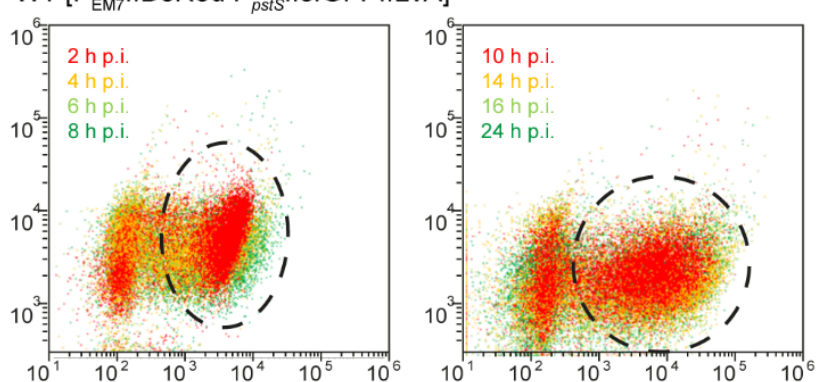

F $\Delta s s a V\left[P_{\text {EM }}::\right.$ DsRed $P_{p s t s}::$ sfGFP::LVA]
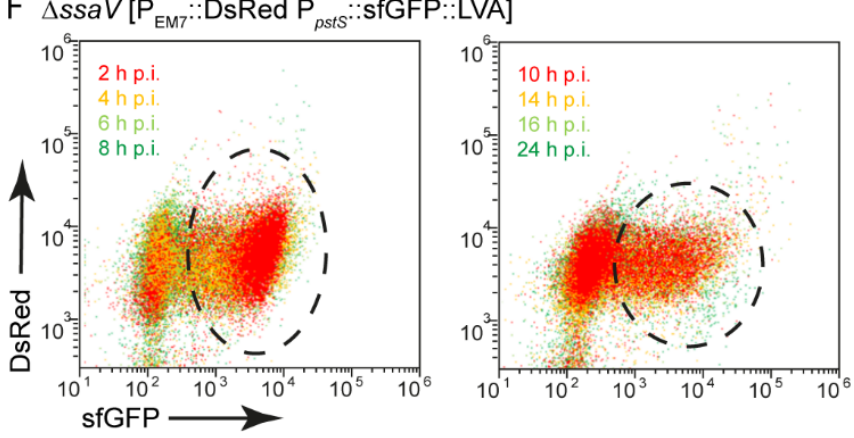
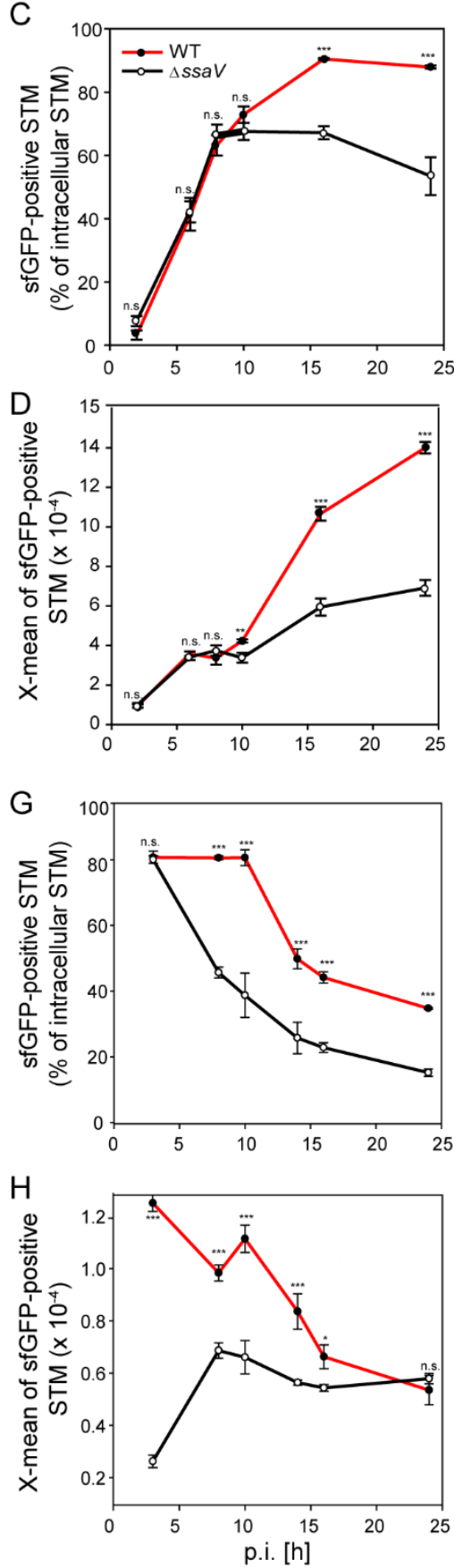

Figure S 7: Time-resolved changes in phosphate availability in HeLa cells and RAW264.7

macrophages. HeLa cells or RAW264.7 macrophages were infected with STM WT (A, C, E, $\mathrm{G}$, red lines) or $\Delta s s a V(\mathrm{~B}, \mathrm{D}, \mathrm{F}, \mathrm{H}$, black lines) strains harboring phosphate reporter p5440 at a MOI of 5. Host cells were lysed at various time points p.i., released STM were fixed and

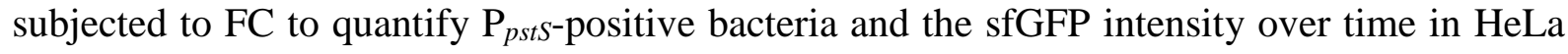
cells or RAW264.7 macrophages. Mean values and standard deviations indicate the size of the sfGFP-positive populations (C, G) and the X-means of sfGFP intensities (D, H) of triplicates at 
bioRxiv preprint doi: https://doi.org/10.1101/2020 10.23.351551; this version posted October 23, 2020. The copyright holder for this preprint (which was not certified by peer review) is the author/funder, who has granted bioRxiv a license to display the preprint in perpetuity. It is made available under aCC-BY-NC-ND 4.0 International license.

Intracellular Salmonella phosphate availability

1024 various time points p.i. as indicated. Representative data for STM WT and $\Delta s s a V$ strains in

1025 HeLa cells (A, B) or RAW264.7 macrophages (E, F) are show for various time points p.i.

1026 Statistical analyses are indicated as for Figure 3.

1027 
1028 Table S 1. Oligonucleotides used in this study

\begin{tabular}{|c|c|}
\hline Designation & Sequence $5^{\prime}-3^{\prime}$ \\
\hline Vf p4889 & ATGCGCAAAGGCGAAGAACTGTTTACCGGTGTGGTGCCGA \\
\hline Vr p4889 & GGCCGGCATCACCGGCGCCACAGGTGCGGTTG \\
\hline $1 \mathrm{f} \mathrm{P}_{p s t s}$ & CAACCGCACCTGTGGCGCCGGTGATGCCGGCCGCCTCTTTGTCCTGGCGAT \\
\hline 1r P psts & CACCGGTAAACAGTTCTTCGCCTTTGCGCATAATGTCTCCTGCACGGTTTCG \\
\hline Vf-p4889-exEM7 & AACCGCACCTGTGGCGCCG \\
\hline Vr-p4889-exEM7 & TAGTGGTACCCGGGAAAGAGGAGAA \\
\hline If apeE-p4889 & CTGTGGCGCCGGTGATGCCGGCCTTATAAACAGCAGCCTATGA \\
\hline 1r apeE-p4889 & CAGTTCTTCGCCTTTGGGCATCCGATGTTCCTTAATGTTATT \\
\hline 1f $P_{\text {ssaG }}-\mathrm{p} 4889$ & CTCTTTCCCGGGTACCACTACAATGCTTTTCCTTAAAATAAATACA \\
\hline 1r $\mathrm{P}_{\text {ssaG }}-\mathrm{p} 4889$ & GCCACAGGTGCGGTTAGACGGTAGATTAGCCTT \\
\hline Vf-p4889 ex EM7 & CCACCATACCCACGCCGAAACAA \\
\hline Vr-p4889 ex EM7 & ATCGATAGCTGGTCGACAACCAT \\
\hline If p4507 $\mathrm{P}_{\text {uhpt }}$ & TCGGCGTGGGTATGGTGGTGCCGGCCACGATGCGTC \\
\hline
\end{tabular}


Intracellular Salmonella phosphate availability

1r p4507 DsRed

p4889-LVA SDM For

SfGFP-LVA Rev

pEM7-RFP For

RFP-T2 Rev
TTGTCGACCAGCTATCGATGAAGCTTCTACAGGAACAGGTGGTG

ctacgctttagtagctTAATAAAAGCTTCTGTTTTGG

ttttcgtcgtttgcagcTTTATACAGTTCATCCATGC

GCGGCGGCCGCGTTTAAACCCATGGACGTGTTGACAATTAATCATCGGCATAGTATATCGGCATAGTATAATACGACTCAGGGCCC GATATCGGTACCGGGAAAGAGGAGAAAAGTATG

GCGGAGCTCAGTTTGTAGAAACGCAAAAAGGCCATCCGTCAGGATGGCCTTCTGCTTAATTTGATGCCTGGAATTCGTTAACACCA GCTATCGATCCATGGTT 